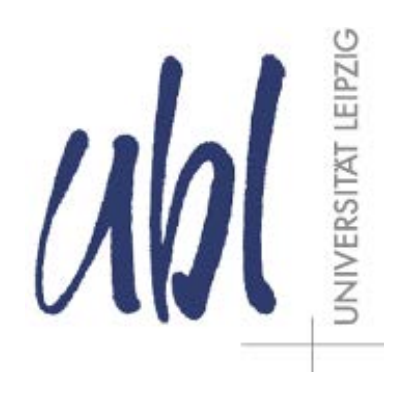

Institute of Medical Physics and Biophysics

Medical Department, Leipzig University

Author Manuscript

(C) 2014. This manuscript version is made available under the CC-BY-NC-ND 4.0 license

http://creativecommons.org/licenses/by-nc-nd/4.0/

Published in final edited form as:

Critical Reviews ${ }^{\mathrm{TM}}$ in Immunology, 2014; 34:433-54.

Available at: http://dx.doi.org/

10.1615/CritRevImmunol.2014011600.

\title{
DIFFERENCES IN INNATE IMMUNE RESPONSE BETWEEN MAN AND MOUSE
}

\author{
Josefin Zschaler ${ }^{1,2, *}$, Denise Schlorke ${ }^{1,2, *}$ \& Juergen Arnhold ${ }^{1,2}$ \\ ${ }^{1}$ Institute for Medical Physics and Biophysics, Medical Faculty, Leipzig University, Leipzig, \\ Germany \\ ${ }^{2}$ Translational Centre for Regenerative Medicine (TRM), Leipzig University, Leipzig, Germany \\ * Both authors contributed equally to this work.
}

\section{Abstract}

Mouse strains are frequently used to model human disease states, to test the efficiency of drugs and therapeutic principles. However, the direct translation of murine experimental data to human pathological events often fails due to sufficient differences in the organization of the immune system of both species. Here we give a short overview of the principle differences between mice and humans in defense strategies against pathogens and mechanisms involved in response to pathogenic microorganisms and other activators of the immune system. While in human blood mechanisms of immune resistance are highly prevailed, tolerance mechanisms dominate for the defense against pathogenic microorganisms in mouse blood. Further on, species-related differences of immune cells mainly involved in innate immune response as well as differences to maintain oxidative homeostasis are also considered. A number of disease scenarios in mice are critically reflected for their suitability to serve as a model for human pathologies. Due to setbacks in these studies, novel mouse models were created to bridge the immune system of both species: humanized mice. Accordingly, a special section of this review is devoted to new results applying humanized mouse models taking limitations and prospects into account.

\section{Abbreviations}

BPI: bactericidal/permeability-increasing protein; CD: cluster of differentiation; FPR: formyl peptide receptor; HLA: human leukocyte antigen; HNP: human neutrophil peptide; HSC: human stem cells; IDO: indoleamine-2,3-dioxygenase; IFN: interferon; IL: interleukin; IL2ry: 
interleukin 2 receptor gamma; iNOS: inducible nitric oxide synthase; IRG: p47 immunityrelated GTPase; LPS: lipopolysaccharide; MHC: major histocompatibility complex; MPO: myeloperoxidase; RAG: recombination-activating gene; TLR: Toll-like receptor; TNFa: tumor necrosis factor $\alpha$

\section{Keywords}

innate immunity, leukocytes, mouse model, resistance, tolerance

\section{INTRODUCTION}

In humans, pathogens, traumata, and antigens can activate cells of the innate and in many cases also of the adaptive immune system. Immune cell activation contributes to neutralization and elimination of the initiating agents and is directed to abolish any harm from the host. However, immune stimulation results sometimes in long-lasting inflammatory events and disease states. Finding an adequate and person-specific therapy for such pathological scenarios is a great challenge for physicians and researchers. Laboratory mouse strains are widely used to test drugs and to develop novel therapeutic strategies on artificially induced diseases.

It is quite obvious that man and mouse are different in respect to their size, behavior, lifespan, living conditions, ecological niches, and other properties. Nevertheless, the leading model system for biomedical research is the mouse. Almost 100 years ago, malting programs established in the Jackson Laboratory created the first inbred mouse strains used for cancer research. ${ }^{1}$ Today, various modern mouse strains are used in laboratories worldwide to test drugs in disease models because of their short lifetime, easy reproduction, comparable low costs, public acceptance, ease of genetic manipulation, and the possibility to keep them under standardized conditions.

Undoubtedly, detailed investigations of similar molecular pathways in mice considerably increased our knowledge about the corresponding immune reactions in humans. For example, elucidation of signaling via toll-like receptor 4 in mouse strains provided important useful information about basic mechanisms in human innate immunity. ${ }^{2-4}$ It is also evident that in some murine models of human diseases, an identical point mutation is responsible for the development of the same disease phenotype in both species as in the pathogenesis of the Burkitt lymphoma ${ }^{5}$ or in leukocyte adhesion defect syndromes. ${ }^{6}$

Despite these and other commonalities, adequate translation of results from animal experiments to humans is often highly challenging, frustrating, and in many cases very unsuccessful. Several items have been summarized that make the mouse to an improper model for human diseases. ${ }^{7}$ These constraints are the use of inbred mice strains that may have homozygous recessive defects, application of disease protocols that are often far from reality, large evolutionary distance between both species, and differences in organization of the immune system. For example, the $M x 1$ gene, which provides resistance to influenza virus infection, is deleted in most standard laboratory inbred mouse strains. Mouse strains originating from wild mice uniformly carry the $M \times 1$ gene. ${ }^{8}$ The most serious problem in translation of mouse model data to human diseases is that man and mouse developed divergent strategies during evolution to combat infections, which result in a different management of the accompanying inflammatory process.

As it is impossible to cover all immunologically relevant differences between both species, this review focuses on the basic differences in the organization of immune responses and 
the differences among cells of the innate immune system, as well as the critical reflection of disease models.

\section{THE MOUSE GENOME IN COMPARISON TO MAN}

\section{A. General Genome Properties}

Modern genetic approaches allow detailed analysis of genomes in, inter alia, man and mouse. Due to a common precursor of both species, substantial amounts of orthologous genes are found together with a sufficient number of species-relevant individual genes. The first mouse genome sequence was published in 2002. ${ }^{9}$ Improved methodological approaches led to publication of a refined version of the mouse genome in 2009. ${ }^{10}$ All data given here are referred to this second version.

Novel improved sequencing approaches revealed that the number of genes in mouse is 20,210 , while humans have only 19,042 genes (see also Table 1 ). There are 15,187 genes of both species that are functionally closely related, indicating their existence in an ancient common precursor species living about 90 million years ago as rodent and primate lines were separating. That means $75 \%$ of mouse genes and $80 \%$ of human genes are orthologs. These one-to- one orthologs exhibit median nucleotide and amino acid identities of $85.3 \%$ and $88.2 \%$, respectively. ${ }^{10}$

Interestingly, the number of duplicated genes is higher in mouse than in man (3767 versus 2941). In mice, duplicated genes encode mostly olfactory and vomeronasal functions, pheromone senses, or are associated with reproductive functions, for instance, with processes during spermatogenesis. ${ }^{10}$

\section{B. Essential and Nonessential Orthologous Genes}

Another study compared orthologs of essential genes in humans and mice. ${ }^{11} \mathrm{~A}$ total of 1716 human genes were identified as genes with a clear disease-related association. Of this group 1450 genes have one-to-one orthologs in the mice genome. From this gene pool, 120 human genes were selected as essential genes, implying that deletions of these human genes are associated with early death (before puberty) or infertility. Proof of essentiality of these genes in mice revealed that 27 genes were nonessential and 93 genes were essential. The criterion for essentiality in mice was death before reproductive age or infertility in the corresponding knockout animal.

Twelve of 27 nonessential genes in mouse are related to degradation of cellular waste and toxins within lysosomes. Comparison between metabolic rates revealed that humans produce about 18 times more waste products until they reach the reproductive age, than mice, per unit of body mass. Hence, diseases concerning waste management are more important in human beings than in mice. In mice, there is a tendency for the development of such diseases at more advanced age of life. Consequently, knowledge of human diseases gained from mouse models is only basic, but will not yield sufficiently accurate information. This especially holds for neurologic diseases associated with defective waste product elimination. ${ }^{11}$

\section{RESISTANCE VERSUS TOLERANCE}

\section{A. Main Immunological Defense Principles}

Survival of a species depends not only on numerous adaptations to environmental conditions but is also determined by a well-functioning immune system. The latter is 
responsible for recognition and elimination of pathogens as well as different self- and environmental antigens, and to hold any threat at a low extent to the whole organism coming from these agents.

Two general principal mechanisms exist to combat deleterious pathogens and antigens, resistance, and tolerance. ${ }^{12,13}$ Resistance mechanisms are directed to deactivate and eliminate unwanted microbes and other pathogens as early as possible. Thus, a number of fine mechanisms exist for activation of host immune cells after recognition of specific pathogen markers. This immune activation keeps the number of invading pathogens at a low level.

In contrast, tolerance mechanisms are developed to hold any threat to the host at a low level coming from pathogens although they might be present in a high number in some host compartments. Thus, tolerance ensures survival of host cells and tissues as well as host functioning despite a high load of pathogens. However, host protecting mechanisms should exist to hold the total number of pathogens below a given - for the host tolerablethreshold.

Considering systemic effects of the immune defense organization, in humans resistance mechanisms dominate, while in mice tolerance mechanisms are highly prevailed. During the last 30 years, immunologists focused mainly on investigating and understanding resistance despite exploring tolerance mechanisms. ${ }^{12,13}$ Although a number of examples exist for the latter, the knowledge about these mechanisms is much lower. Important differences between man and mouse regarding main immunological defense strategies are summarized in Fig. 1.

\section{B. Response to Toll-like Receptor Ligands in Human and Mouse Blood}

Recognition of pathogen- and damage-associated molecular patterns is important to minimize any threat to the host organism. Toll-like receptors (TLRs) as a prominent class of pattern recognition receptors activate the innate immune system by binding selected constituents of pathogenic microorganisms and of the damaged host tissue. Gram-negative bacteria are known to express lipopolysaccharide (LPS) that activates immune cells via TLR4 signaling. ${ }^{3}$ Other examples of TLR ligands are bacterial lipopeptides and lipoproteins, lipoteichoic acid, heat shock proteins, zymosan, flagellin, and double-stranded RNA from viruses. ${ }^{14}$ Up to now, 10 TLRs are known for humans and 12 for mice. Although many TLRinduced signaling pathways are highly conserved between man and mouse, there are a number of differences mostly related to TLR expression and ligand specificity. Important differences in TLR properties and signaling are summarized in Table 2.

In humans, TLR ligands cause an inflammation including sequelae during host protection against infections. A similar scenario occurs in noninfectious diseases where an inflammatory process is relevant, such as in arteriosclerosis, Alzheimer's disease, and some forms of cancer. This kind of immune response corresponds to resistance, with the main aim to limit the burden of pathogenic microorganisms. In different human inflammatory scenarios, a common strategy of genetic responses under involvement of TLR signaling was recently reported. ${ }^{15}$

In contrast to humans, mice are hardly challenged by TLR agonists. They developed tolerance strategies against the TLR4 agonist LPS, the TLR2 agonist peptidoglycanassociated lipoprotein, and other inflammatory agonists such as the superantigen staphylococcal enterotoxin B. ${ }^{16,17}$ 
These immunological differences are further underlined by the noxious effect of LPS. In humans, a LPS dose of 2-4 ng/kg body mass induces fever and cytokines, and about $15 \mu \mathrm{g} / \mathrm{kg}$ causes already severe disease with shock. ${ }^{18-21}$ In mice, the median lethal dose is reported to be $10 \mathrm{mg} / \mathrm{kg} \cdot{ }^{17,22,23}$ Thus, LPS doses inducing severe disease with shock are several orders of magnitude higher in mice than in humans.

These effects were carefully evaluated by measuring cytokine release after challenging human and mouse blood with LPS or peptidoglycan-associated lipoprotein. ${ }^{17}$ When mouse serum was added to isolated human and mouse mononuclear cells it diminished the cytokine release more efficiently than human serum. Thus, mouse serum contains a yet unknown factor that is responsible for this effect. This factor was not inactivated by heat treatment but was sensitive to treatment with trypsin. Furthermore, mouse serum markedly reduced the mRNA encoded for tumor necrosis factor $\alpha$ (TNF $\alpha$ ) in monocytes. However, mRNA expression of factors (e.g., MyD88s, SOCS1, SOCS3) which are known to limit TLR4 signaling and reduce TNF $\alpha$ production was not upregulated. ${ }^{17}$

Due to the lack of clear data, it is only possible to speculate about the significance of this finding for the immunological response to LPS in mice. Maybe there are differential responses in various compartments in mice that would limit the appearance of a systemic inflammation due to suppressive activity of serum components from a local inflammatory event. An inverse correlation between LPS sensitivity and suppression of TNF $\alpha$ production was not only found for mouse serum but also for other animal sera. ${ }^{17}$ Hence, an appropriate model system for LPS sensitivity in human has to be chosen carefully.

\section{Different Responses to Interferon $\gamma$}

During inflammation, the cytokine interferon $\gamma$ (IFN $\gamma$ ), released by specialized immune cells, is able to trigger innate immune response in humans and rodents. In mice, IFN $\gamma$ induces the expression of 18 different genes of GTPases, the so-called p47 immunity-related GTPase (IRG) proteins. These proteins induce host response against bacterial and protozoan pathogens as shown by a dramatic increase in susceptibility to pathogens in IRG knockout mice. $^{24}$

One antimicrobial effect of IRG proteins in mice is the induction of autophagy of pathogenloaded macrophages. This process does not require reactive oxygen and nitrogen species. ${ }^{25}$ Originally, autophagy has been described as a fundamental cellular adaptation to starvation in eukaryotes, whereby cells autodigest long-lived cytosolic macromolecules. ${ }^{26}$ Interestingly, several groups demonstrated that intracellular pathogens are also sequestered into autophagosomes, vacuoles with a characteristic double membrane, for degradation in autolysosomes. This autophagy process can be induced in murine mycobacterial-loaded macrophages by IFN $\gamma$. Thereby, the IRG protein LRG-47 is of importance stimulating the translocation of an autophagy factor (microtubule-associated protein 1A/1B-light chain 3) from the cytosol to the autophagosomal membrane promoting the maturation of mycobacterial phagosomes. The autophagic pathway overcomes the Mycobacterium tuberculosis induced phagolysosome biogenesis block. ${ }^{25,27}$

Further, IRG proteins in mice induce vesiculation, destruction of Toxoplasma gondii parasitophorous vacuolar membranes, ${ }^{28}$ and modify lipid traffic in immune cells after escaping pathogens. ${ }^{24}$

In striking contrast, humans express only two members of IRG proteins. None of the genes of this protein family are induced by IFN $\gamma$. Nevertheless, the human IRGM protein 
participates in IFN $\gamma$-induced autophagy processes in human macrophages to eliminate intracellular mycobacteria. ${ }^{27}$ However, human IRGM does not display any additional antimicrobial activity. ${ }^{24}$

General differences in human and mouse immune response also lead to different strategies of the pathogens to survive. In mice, IFN $\gamma$ induces three different IRG genes for resistance against the primarily human pathogen Chlamydia trachomatis. Thereby, the IRG proteins trigger a rerouting of bacterial inclusions in mouse embryonic fibroblasts to autophagosomes. However, the mouse pathogen Chlamydia muridarum adapts to the autophagy process and blocks the interaction of IRG proteins with vacuole membranes. ${ }^{29}$

In contrast, human cells resist Chlamydia trachomatis by expression of indoleamine 2,3dioxygenase (IDO) in response to IFN $\gamma$ or IFN $\gamma+$ LPS. Thereby, IFN $\gamma$ is of special importance as neither LPS nor Chlamydia alone is known to induce IDO. Indoleamine 2,3-dioxygenase causes a depletion of tryptophan that is necessary for pathogen growth. To overcome the lack of tryptophan, Chlamydia trachomatis expresses tryptophan synthase. ${ }^{30}$ Most mouse cell lines cope with Chlamydia or IFN $\gamma$ stimulation by expression of inducible nitric oxide synthase (iNOS or NOS2) but do not express IDO. In human cells, iNOS is never induced by this pathogen or treatment with IFN $\gamma$. The outcome of NO, however, depends on the mouse cell line type. Further on, blockade of NO synthesis in mice only partially rescued Chlamydia growth indicating additive effects of NO to the antichlamydial activity of IRG proteins. ${ }^{30}$

\section{SELECTED PROPERTIES OF INNATE IMMUNE CELLS}

\section{A. White Blood Cell Composition}

In adult species, the balance between leukocytes in man and mouse is quite different. C57BL/6 mice contain 10-25\% neutrophils, 75-90\% lymphocytes, and about 2\% monocytes. ${ }^{31}$ For CD-1 mice, $15-20 \%$ neutrophils (300-2000 cells/ $\mu \mathrm{L}$ ) and $50-70 \%$ lymphocytes (1000-7000 cells/ $\mu \mathrm{L})$ were reported. ${ }^{32}$

In contrast, humans have $50-70 \%$ neutrophils (3500-7000 cells $/ \mu \mathrm{L}$ ) and $20-40 \%$ lymphocytes (1400-4000 cells/ $\mu \mathrm{L}) .^{32}$ The crucial role of neutrophils in humans is not only reflected in terms of quantity but also in the functional importance as described in the following section.

\section{B. Neutrophil Granulocytes}

Neutrophil granulocytes are the first cells accumulating at the inflammatory site from peripheral blood followed by monocytes. With the release of highly aggressive proteins and reactive metabolites they contribute to host defense. The most prominent task of neutrophils is the phagocytosis of bacteria. An uncontrolled activation can result in tissue injury. However, neutrophils are also important as regulators of inflammatory processes and are involved in acquired immunity by activation of T-cells, antigen presentation, or Tcell suppression. ${ }^{33}$

\section{Chemotaxis and Diapedesis of Neutrophils}

During the course of inflammation, neutrophils are recruited from the peripheral blood to the site of inflammation by chemoattractants. In this process, differences between the human and murine system emerged. While interleukin (IL) 8 was identified as being the most important chemoattractant for human neutrophil recruitment, an orthologous counterpart is absent in mice. ${ }^{34}$ In contrast, mice express lungkine as attractant for 
neutrophils in lung and other functional homologues of IL-8. ${ }^{35,36}$ Directional migration of neutrophils is furthermore stimulated by chemoattractive $\mathrm{N}$-formylated peptides [with $\mathrm{N}$ formyl-methionine-leucine-phenylalanine (fMLF) as prototype] that are formed, among others, by gram-negative bacteria. Only two formyl peptide receptors (FPR), FPR1 and FPR2, are expressed in human neutrophils. On the contrary, at least three members, Fpr1, Fpr2, and Fpr-s1 (also known as LXA4R), are expressed in murine neutrophils. ${ }^{37-42}$ However, their fMLF-affinity in comparison to the human FPR1 is low.

In the next step of leukocyte extravasation, rolling adhesion, further species-specific differences emerged. For instance, L-selectin from human but not from murine neutrophils binds to E-selectin. ${ }^{43}$ In addition, the treatment of mouse neutrophils with a protease mix eliminated the binding of P-selectin and E-selectin. ${ }^{44}$ However, on human neutrophils proteases abrogated only the P-selectin binding site, whereas E-selectin binding was only slightly affected. ${ }^{45}$ This might be attributed to cell-surface glycosphingolipids of human leukocytes as possible binding partners of E-selectin on endothelia cells. ${ }^{46}$ Furthermore, distinct glycosyltransferases synthesize E-selectin ligands in human and mouse granulocytes. ${ }^{47}$

\section{Granule Constituents in Neutrophils}

Neutrophils are characterized by their microbicidal molecules packed in granules and released upon cell activation. Due to remarkable differences in expression and/or activity between man and mouse, particular attention has to be paid in research connected to neutrophil action. Differences are summarized in Table 3.

Prominent components of azurophilic granules in human neutrophils are defensins, small cysteine-rich cationic proteins that bind to microbial membranes and induce pore-like membrane defects. Three of the four human defensins in neutrophils (human neutrophil peptide HNP-1, HNP-2, HNP-3) account for $5-7 \%$ of total protein content and about 30$50 \%$ of protein content in azurophilic granules. ${ }^{48}$ In contrast, neutrophils from mice do not express defensins. ${ }^{49}$ In mice, Paneth cells, present in the crypts of the small intestine, express at least six different defensins, ${ }^{50}$ whereas in humans only two kinds of defensins (HNP-5, HNP-6) are found in these cells. ${ }^{51}$ Mouse defensins are processed by matrix metalloproteinase-7, while human defensins from Paneth cells are processed by trypsin. ${ }^{51,52}$

Another member of the host defense peptides is the bactericidal/permeability-increasing protein (BPI). This cationic peptide fulfills antimicrobial activities by directly interacting with membranes of gram-negative bacteria, neutralizing the endotoxic effects of LPS by binding, and thereby contributing to phagocytosis by opsonizing bacteria. ${ }^{53}$ In humans, BPI is mainly expressed in neutrophils during the promyelocyte stage of differentiation and then stored in azurophilic granules. ${ }^{54}$ In mice, its expression pattern differs and under resting conditions $\mathrm{BPI}$ is mainly found in testis, epididymis, and only at low levels in myeloid cells. ${ }^{55}$

Finally, one further key component of human neutrophils, the heme-containing enzyme myeloperoxidase (MPO) that is stored in large amounts in azurophilic granules of resting cells, differs in its expression between man and mouse. Myeloperoxidase is able to catalyze a wide range of one- and two-electron substrate oxidations. On the one hand, MPO contributes with special products to apoptosis induction in neutrophils and, thus, to termination of inflammatory response. On the other hand, MPO released from necrotic cells promotes an inflammation by recruiting neutrophils and chemical modification of proteins and other tissue constituents. ${ }^{33}$ The myeloperoxidase level in mice neutrophils is 
about $10-20 \%$ that of human cells as determined by activity measurements. ${ }^{56,57}$ Differences exist also in the organization of the MPO promoter region between both species. ${ }^{58}$

Furthermore, lower levels of ß-glucuronidase, lysozyme, and alkaline phosphatase were reported in mice neutrophils in comparison to human ones. ${ }^{57}$ In conclusion, the composition of granules significantly differs between human and mouse neutrophils. Various antimicrobial molecules, which contribute decisively to host defense in human neutrophils, are less abundant in mouse neutrophils.

\section{Eosinophil Granulocytes}

Eosinophil granulocytes constitute only $1-3 \%$ of the white blood cell count both in humans and mice. Upon production in bone marrow, they circulate in blood or, also despite absence of infection, reside in different organs (e.g., secondary lymphoid tissue, thymus, gastrointestinal tract) with so far unknown function. Eosinophils are specialized in host defense against parasites, but overwhelming activities have also been described in allergic response and asthma pathogenesis. ${ }^{59}$

Interspecific varieties between human and murine eosinophils are only scarcely described. Nevertheless, differences exist in cell morphology (size, granularity), cell surface markers (e.g., Gr1 is only present in mice), mode of degranulation (compound and classical exocytosis are not observed in mice), and mediators released upon stimulation (eosinophil peroxidase is not released in mice upon fMLF, GM-CSF, PMA stimulation), as well as restricted expression of the chemokine eotaxin-3 to humans. ${ }^{60}$ The latter point is of importance especially in asthma research, as eotaxin-3, which is heavily expressed in lung epithelia, triggers a second phase of eosinophil migration in mild asthmatics. ${ }^{61,62}$ In mice, eotaxin- 3 is only present as pseudogene and murine eosinophils do not respond to it. ${ }^{63}$ This suggests different roles of eotaxins in the pathogenesis of asthma.

\section{Monocytes and Macrophages}

Macrophages reside in virtually all tissue differentiated from circulating peripheral blood monocytes where they engulf apoptotic and necrotic cells as well as pathogens upon tissue damage or infection. In addition to their role as immune effector cell, macrophages are important for tissue homeostasis, antigen presentation, and immune regulation. ${ }^{64}$

\section{Subsets of Macrophage Activation}

Polarization of murine macrophages into M1 (classically activated) or M2 (alternatively activated) macrophages on the basis of gene expression profiles and identification of surface markers is often used to explore the different natures of macrophages, and a panel of markers exists for these subsets..$^{65}$ This polarization was introduced to have clear parallels to T-helper cell functions. In human macrophages, the identification of M1 and M2 subsets is more challenging because of species-related differences in macrophage polarization markers. For example, the M2 mouse markers arginase 1, Relma (Fizz1), matrix metalloproteinase-1, and Chi3l3 (Ym1) are not expressed in humans, while Chi3/2 (Ykl39), fibrinoligase, and platelet-derived growth factor $\mathrm{C}$ are not found in mice. ${ }^{66}$

\section{Arginine Metabolism in Macrophages}

Great differences exist between human and murine macrophages in arginine metabolism. In mice, iNOS plays an important role in producing large amounts of NO and L-citrulline. The expression of this enzyme is upregulated by several orders of magnitude upon incubation of murine macrophages with LPS and IFN $\gamma .{ }^{67}$ However, in human macrophages iNOS is not expressed and $\mathrm{NO}$ is not produced by these agents. ${ }^{65,68}$ 
The lack of iNOS expression in human macrophages remains puzzling. There are discussions about dismissive factors in culture media and the lack of required epigenetic alterations. ${ }^{65}$ Murine macrophages are able to synthesize the iNOS cofactor tetrahydrobiopterin. This cofactor is not formed in human macrophages. ${ }^{69}$ Even the addition of this cofactor to isolated human macrophages did not induce NO production in stimulated cells. ${ }^{70}$

Contrary, there are several reports about a strong expression of iNOS in human macrophages and other cells and an enhanced NO production in these cells under severe disease conditions. ${ }^{71-73}$ However, mechanisms for this iNOS activation remain unknown. Maybe other cytokines and cytokine combinations cause this activation of iNOS in human macrophages. For example, interferons $\alpha$ and $ß$ are known to induce expression of iNOS in human macrophages. In contrast, murine macrophages are unable to produce $\mathrm{NO}$ in the presence of IFN $\alpha$. Further cytokine combinations known to produce NO in human macrophages are IL4+IFN $\gamma$ and IL-4+anti-CD23. ${ }^{72}$

Arginine is also metabolized by arginase to L-ornithine and urea. In mice, cytoplasmic arginase type- 1 is upregulated in alternatively activated macrophages. It antagonizes the activation of iNOS in classically activated macrophages. ${ }^{74}$ In this way, activation of arginase type-1 dampens tissue damage by pro-inflammatory agents associated with proinflammatory cytokines and iNOS activation but favors parasite survival and proliferation. ${ }^{75}$ In unstimulated murine leukocytes, there is no expression of arginase type-1. Contrarily in humans, the arginase type- 1 is constitutively expressed in azurophilic granules of neutrophils, where it contributes to antimicrobial defense likely by arginine depletion in the phagolysosome. ${ }^{76}$ This arginase expression is insensitive to Th2 cytokines. In traumatic patients, expression of arginase type- 1 is increased in mononuclear cells. ${ }^{77}$ This enzyme is not induced by IL-4 or IL-13 in human monocytes and macrophages in contrast to murine cells. ${ }^{78}$

\section{E. Killing of Pathogenic Microorganisms}

In mice, several essential genes have been knocked out with the consequence of an impaired killing of selected pathogens. ${ }^{79}$ Knockout of phox components of NADPH oxidase is detrimental in both mice and humans. The corresponding human disorder is known as chronic granulomatous disease. These patients suffer similarly to the corresponding knockout mice from recurrent infections. ${ }^{80,81}$ In the case of myeloperoxidase, several adverse experimental scenarios with MPO-deficient mice have been described. ${ }^{82-84}$ Myeloperoxidase deficiency is common in humans but usually without serious problems. The only problem in human MPO deficiency concerns fungal infections in some immunosuppressive patients..$^{85}$ Killing of Candida albicans is completely abolished by human neutrophils in the absence of MPO. ${ }^{85}$ In contrast, MPO-deficient mouse neutrophils exhibit a residual ability to kill this pathogen. ${ }^{83}$ Knockout mutations for elastase, cathepsin G, or inducible nitric oxide synthase also impaired the ability of these mice to deactivate a number of pathogens. ${ }^{79}$ For the human counterpart, any disease scenarios with primary deficiency of these enzymes are largely unknown.

Collectively, these examples evidence that in addition to the NADPH oxidase and myeloperoxidase pathway different synergistically acting components are involved in antimicrobial defense in human and murine phagocytes. While a broad range of small proteins, such as defensins and others, is characteristic of human leukocytes, nitrogen reactive species have a higher impact in microbe killing in mice. ${ }^{79,86}$ Especially the double iNOS and gp91phox knockout mouse is very susceptible to spontaneous infections. ${ }^{87}$ 


\section{F. Natural Killer Cells}

Natural killer cells are lymphocytes of the innate immune system with both cytotoxicity and cytokine-producing effector function. They are able to destroy compromised host cells such as tumor cells and virus-infected cells limiting their spread und subsequent tissue damage. Although signaling pathways are largely conserved in human and murine killer cells, there are some differences in cell biology and receptor composition between both species. ${ }^{88,89}$

In mice, the activity of natural killer cells in spleen and blood is high at 4-10 weeks of age. In humans, their activity is relatively stable throughout the whole lifetime. In lung, mice have high activity of natural killer cells, whereas their activity is low in man. Expression of Fc-receptors on natural killer cells is much higher in humans than in mice. ${ }^{88}$

In mice, killer cells use Ly49 proteins as inhibitory receptors for major histocompatibility complex (MHC) I molecules. This protein family is absent in humans. Here proteins of the killer cell inhibitory receptor family, which is highly divergent to Ly49 proteins, are used as inhibitory receptors on the surface of natural killer cells. ${ }^{90}$

\section{G. Mast Cells}

Mast cells are large granulated cells which undergo their terminal stage of maturation after migration into vascularized tissues. Mast cells express IgE-specific Fc receptors (FcER) on the cell surface. Upon stimulation and receptor cross-linking by immunoglobulin $E$ and others, human mast cells release histamine, lipid mediators, cytokines, proteoglycans, and proteases. Histamine is released upon sensitization from mast cells in response to immunoglobulin $\mathrm{E}$ in humans. Although histamine is known to be present in mice blood and cell compartments, serotonin is responsible for physiological effects in anaphylactic reactions in this species. ${ }^{32}$ Murine mast cells contain significant amounts of serotonin, which is found only in few quantities in human mast cells. ${ }^{91}$

Production of TNFa dominates in murine mast cells, while human mast cells are an important source of IL-5, explaining the significant role of human mast cells during recruitment of eosinophils to sites of allergic inflammations. In contrast, murine mast cells resemble more human basophils. For example, IL-3 causes strong responses in murine mast cells and human basophils but only weak response in human mast cells. Murine mast cells and human basophils are also an important source of IL-4, whereas under normal conditions IL- 4 is not produced by human mast cells. Furthermore, murine mast cells express CD14, like human monocytes, and various Toll-like receptors which are not, or only scarcely, found in humans. ${ }^{92}$

\section{H. Ascorbic Acid and Urate}

Inflammatory response and activation of immune cells are accompanied by an enhanced formation of reactive oxygen and nitrogen species that may contribute to tissue damage. Ascorbic acid and urate are important natural molecules with antioxidant properties.

Most rodents including mice and rats, but not guinea pigs, are able to synthesize ascorbic acid from glucose via a cascade of four subsequent enzyme reactions. In the last step, Lgulonolactone reacts with dioxygen to form ascorbic acid. This reaction is catalyzed by Lgulonolactone oxidase which is deficient in humans, other primates, and guinea pigs. In these species, the gene of this enzyme is present as a pseudogene..$^{93}$ Thus, ascorbic acid is not synthesized in man and has to be taken up with food. 
Surprisingly, tissue and blood levels of ascorbic acid are in the same range of order in healthy individuals of man and mouse. ${ }^{94,95}$ The status of ascorbic acid in tissues is determined by numerous factors such as expression of transporters, enzymatic reactions, and redox processes. Man and other mammals, which are unable to synthesize ascorbic acid, express the glucose transporter 1 together with stomatin in their erythrocytes and other cells. This unique transporting system mediates the cellular uptake of dehydroascorbic acid, the oxidized form of ascorbic acid. ${ }^{96}$ In cells, dehydroascorbic acid is rapidly reduced to ascorbic acid..$^{97,98}$ In mice erythrocytes, there is no expression of glucose transporter 1 and no uptake of dehydroascorbic acid. ${ }^{96}$

Despite protecting functions of iron-containing enzymes involved in synthesis of collagen, ${ }^{99}$ carnitine ${ }^{100}$ and dopamine, ${ }^{101}$ ascorbic acid exhibits pronounced antioxidant functions in biological fluids. However, in humans urate has a higher impact on antioxidant defense reactions. The plasma concentration of this end product of purine metabolism exceeds by 160-450 $\mu \mathrm{M}$ that of ascorbic acid being around $60-80 \mu \mathrm{M}$ in healthy individuals. ${ }^{102,103}$ Young wild-type mice have a urate level of about $60 \mu \mathrm{M}$ in serum. ${ }^{104}$

In mice, urate is further metabolized to $(S)$-allantoin via sequential conversion of urate catalyzed by urate oxidase, 5-hydroxyisourate hydrolase, and 2-oxo-4-hydroxy-4-carboxy-5ureidoimidazoline decarboxylase. ${ }^{105}$ In humans, an active urate oxidase is absent because of nonsense mutations. ${ }^{106}$ The gene of 5-hydroxyisourate hydrolase is also inactive in humans, while the gene of the decarboxylase is apparently not expressed in the transcriptome. ${ }^{105}$

The significance of the shift from ascorbate to urate in antioxidant defense during human evolution remains unknown. It is discussed that urate exhibits in addition to antioxidant properties also neuroprotective activities. ${ }^{107}$

\section{SELECTED DISEASE MODELS}

\section{A. Problems in Translation of Disease Data from Mouse to Man}

\section{Cancer Models}

Mouse models of cancer contribute considerably to the knowledge of human cancer biology. Previous studies focused on implantation of human or syngeneic mouse tumor cells under the skin, into the abdominal cavity, or in the organ of origin of an immunecompromised mouse. These xenograft models are relative easy-to-use systems, but genetics and histology of these tumors are frequently not representative of the human ones. Nevertheless, recent advances were made in patient-derived xenografts representing clinical patient diversity. Increasing numbers of genetically engineered mouse models were developed in the recent years focusing on specific oncogene functions with reverse genetic approaches. ${ }^{108}$ These models are based on extensive techniques for genetic manipulation such as conditional and inducible gene targeting, ${ }^{109}$ chromosome engineering, ${ }^{110}$ or transgenic RNAi technologies. ${ }^{111}$ Also forward genetic approaches creating more phenotype-driven mouse models are available. For example, recombinant inbred mouse strains can be used to identify cancer-susceptibility genes. ${ }^{112}$ Also the transposon technique as a mobile genetic element is able to detect novel cancer genes. ${ }^{113}$ These valuable models allow detailed evaluation of mechanisms involved in tumor initiation, progression, and development as discussed in several recent reviews. ${ }^{114-117}$ However, there are still significant restrictions in the recapitulation of biological and clinical aspects of human cancers in mice. Clear species-specific differences between man and mouse exist. For instance, most mouse cells have active telomerase; therefore these cells are transformed more rapidly than 
human cells are. Furthermore, mouse models tend to form relatively few spontaneous metastases or form metastases with divergent tissue specificity. Also drug metabolism and drug affinity to target proteins differ between mice and humans derogating the potential of mice as an effective drug testing model. Various mouse models possess genetic alterations in the germ line or notably in somatic cells representing the predisposition of human cancer rather than human sporadic cancer. Point mutations are typical of genetic alterations in human cancers. In contrast, overexpression or deletion of genes dominates in mouse models of cancer. ${ }^{116}$ Differences in the microenvironment of tumors and the host immune system are further important factors affecting de novo tumor development.

\section{Autoimmune Disorders}

Autoimmune disorders are usually induced by autoantigenes supplied either by active immunization using adjuvants or by infusion of previously activated lymphocytes. In mice, disease induction is highly artificial and therapeutic approaches start mostly before autoimmune challenge. In contrast, drug administration to autoimmune patients begins often after the autoimmune process has become chronic. ${ }^{118}$

Induction of murine autoimmune encephalomyelitis is commonly applied to model myelin degeneration seen in multiple sclerosis. The protective effect of IFN $\gamma$ in the mouse model failed in multiple sclerosis patients as IFN $\gamma$ exacerbates the disease process. ${ }^{119,120}$ On the other hand, pharmacological blockade of interaction between the cellular adhesion molecules VLA4 and VCAM1 is helpful in both murine encephalomyelitis and multiple sclerosis patients. ${ }^{121}$

For the therapy of autoimmune disorders, different approaches with antibodies against Bcell targets have been developed or are under intense investigation. ${ }^{122}$ For example rituximab, a specific anti-CD20 monoclonal antibody, efficiently diminished the titer of pathogenic autoantibodies in a mouse model of inflammatory arthritis. ${ }^{123}$ The majority of rheumatoid arthritis patients showed lower serum autoantibody level and clinical improvement under therapy with this drug. ${ }^{124,125}$ Nevertheless, there are a number of open questions around therapeutic use of rituximab. These open questions concern the long time to clinical response, the unsolved mechanism of action on B-cells, and the application to other autoimmune diseases. ${ }^{122}$

\section{Sepsis}

In humans, the molecular picture of systemic inflammatory response and multiple organ dysfunction syndromes, known as "sepsis" syndromes, is very heterogeneous and the underlying mechanisms are still under debate. The sepsis syndrome is commonly associated with infection, inflammation, and complex activation of other protecting systems, but also especially at later stages, with suppressed immune functions, release of cytotoxic components, and organ failure. In severe cases, multiple organ dysfunctions, e.g., acute kidney injury, lead to a lethal outcome. ${ }^{126}$

Several experimental approaches have been developed to induce sepsis in murine models. These approaches are the application of pathogenic bacteria and their products such as endotoxin infusion, as well as the disruption of protective barriers, as in the model of cecal ligation and puncture. ${ }^{126}$ Although these models reflect well some features of human sepsis, translation of their data is problematic. As outlined in Sec. III. B, mice are generally less sensitive to LPS than humans. Therapies with anti-TNF $\alpha$ or anti-IL1, which gave promising results in LPS-treated mice, ${ }^{127}$ did not improve survival of septic patients. ${ }^{128,129}$ In the murine model of cecal ligation and puncture, fecal material penetrates after colon 
perforation into the peritoneal cavity and triggers immune responses typical of human sepsis. However, this model fails to develop reproducible organ injury and the outcome of sepsis differs widely among laboratory mice. ${ }^{126}$ Often young, healthy mice are used in these studies. It is more realistic to use already sick animals when sepsis is induced. For example, mice with restricted kidney function developed more severe sepsis. ${ }^{130}$

Pathogenesis of sepsis is connected to nitric oxide metabolism, a critical regulator of vasodilation and vascular homeostasis, but it interferes also with cellular oxygen utilization and the excessive formation of oxidants, thereby stimulating an inflammation. Interestingly, in septic mice, a much higher plasma level of nitric oxide metabolites is observed than in septic patients, indicating that mice are more resistant to pathological NO effects. ${ }^{131,132}$

A further important factor contributing to organ dysfunction in severe sepsis is an excessive intravascular hemolysis. ${ }^{133,134}$ Plasma levels of haptoglobin and hemopexin, which both bind and remove free hemoglobin and heme, respectively, from circulation, are similar in healthy humans and mouse. ${ }^{135-137}$ Both proteins rapidly drop down by excessive release of hemoglobin from red blood cells. Moreover, free hemoglobin efficiently scavenges nitric oxide and limits, thus, the bioavailability of NO. ${ }^{138} \mathrm{~A}$ connection between the different role of $\mathrm{NO}$ in the sepsis of humans and mice and the scavenging of $\mathrm{NO}$ by free hemoglobin after excessive hemolysis could be assumed but is unproven so far.

\section{Asthma}

A further complex inflammatory disease where mice are widely used as animal model is asthma. In mice, antibodies against IL-5 successfully diminished the airway hypersensitivity caused by infiltrated eosinophils in an experimental model of asthma. ${ }^{139}$ In contrast, therapeutic application of anti-IL-5 failed in asthmatic patients in effects on late asthmatic response and airway hyper-responsiveness despite the pronounced decrease of blood and sputum eosinophils. ${ }^{140}$ Apparently, the interplay between various immune cells such as Tcells, eosinophils, mast cells, and others is crucial for late asthmatic reactions. ${ }^{140}$ While plasma exudation dominates in bronchial asthma and allergic rhinitis in humans, only little plasma exudation is observed in mouse airways. ${ }^{141}$ Distribution and properties of eosinophils differ also in human and murine asthma. While human eosinophils release their constituents at inflammatory sites, the mouse counterpart is resistant to degranulation. ${ }^{142,143}$

\section{Atherosclerosis}

Atherosclerosis is a very common disorder in humans. Oxidative modification of lipoproteins and their uncontrolled uptake by macrophages play a key role in atheroma development. However, their exact molecular mechanisms and regulatory aspects are only poorly understood. Human atherosclerotic lesions contain active myeloperoxidase and the myeloperoxidase product chlorotyrosine, indicating the involvement of phagocytes in atheroma formation. ${ }^{144,145}$ Interestingly, myeloperoxidase-deficient individuals developed less pronounced cardiovascular problems than normal persons. ${ }^{146}$ Mice are characterized in comparison to humans by a dominance of high-density lipoproteins over pro-atherogenic low-density lipoproteins and by differences in expression and regulation of genes that control lipoproteins. ${ }^{147}$ For example, humans but not mice express in their blood the cholesterol ester transfer protein that facilitates the transfer of cholesteryl esters between lipoproteins. ${ }^{148}$ As wild-type mice are highly resistant to the development of atherosclerosis, different knockout and transgenic mouse strains (such as apolipoprotein E-deficient mice, low-density lipoprotein receptor-deficient mice, or ApoE*3-Leiden transgenic mice) are 
routinely applied in experimental atherosclerosis research. ${ }^{147,149}$ In atherogenic lesions of the low-density lipoprotein receptor knockout mice, no active myeloperoxidase and chlorotyrosines were detected. Additional MPO deficiency enhanced the atherosclerotic process. ${ }^{83}$ Otherwise, mice deficient for the low-density lipoprotein receptor and additionally transgenic for the human myeloperoxidase gene developed increased atherosclerotic lesions. ${ }^{150,151}$ Thus, different molecular processes dominate in plaque formation in humans and mice.

\section{B. Differences in Response to Disease Inducers between Mouse and Man}

In humans, there were similar genetic responses between burn and trauma patients despite the large heterogeneity in trauma patients concerning demographic aspects, degree of injury, variable amounts of blood received by infusion, and different drug therapies. There was also a sufficient correlation in genetic response between injured patients and patients severely affected by bacterial endotoxins. These data support activation of common immune mechanisms in severe inflammatory diseases in humans. In contrast, there was no correlation in genetic response to the corresponding mouse models for burn, trauma, or endotoxinemia. There was also no correlation between these different mouse models. ${ }^{15}$

In this investigation, great differences were also found in activated and depressed pathways between both species. In humans, Fc-receptor-mediated phagocytosis by mononuclear cells, signaling via TLRs, IL-10, integrins, or B-cell receptors were much more activated activated than in affected mice. Several pathways in T-cells were drastically depressed in human diseases (e.g., iCOS-iCOSL signaling in T-helper cells, calcium-induced T-lymphocyte apoptosis, T-cell receptor signaling), whereas much smaller or no effects were observed in mice models. ${ }^{15}$

\section{The Humanized Mouse}

In order to overcome the obstacles between the different immunological responses of man and mouse, humanized mice were created. These are immunodeficient mice where human cells have been introduced. By this approach, mice with human immunological properties were generated. There are four different models utilized in engraftment of the human immune system into mice, in which either human peripheral blood lymphocytes or human hematopoetic stem cells (HSC) were injected into mice blood and tissue, or where fetal liver and thymus fragments were implanted under the renal capsule in mice. ${ }^{152}$

Immunodeficient mice with a mutation in the $\gamma$-chain of the IL-2 receptor (IL2ry) facilitate considerably the engraftment of human hematopoietic stem cells. Thus, these mice allow studies on human immune cells, including T- and B-cells. ${ }^{153}$

Major disadvantages of the early humanized mouse models were due to species-related differences of cytokines and growth factors and the presence of mouse MHC molecules instead of the human leukocyte antigen (HLA) system. Furthermore, humanized

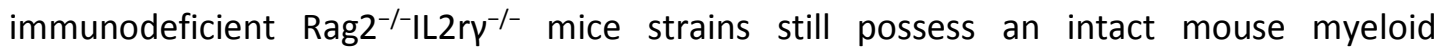
compartment, which might contribute to a low rate of human myeloid cell reconstitution in humanized mouse. In addition, engraftment of mice with human stem cells is only transient, not lifelong, probably due to inefficient integration and levels of HSC decline after 4-6 months in the xenogeneic environment. Furthermore, the transplantation rates differ, even when the same HSC donor is used. ${ }^{152,154}$ 
Various technological approaches try to overcome these problems by developing the "nextgeneration" immunodeficient IL2 $\mathrm{rr}^{-/-}$mice by expressing human transgenes and the targeted inactivation of mouse genes important for the innate immune system.

For instance, Rongvaux et al. replaced the thrombopoeitin gene by its human counterpart

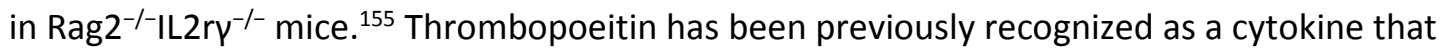
supports self-renewal and maintenance of HSC. In the knock-in technology it led to a multilineage differentiation of hematopoietic cells with an improved ratio of granulocytes to lymphocytes, thereby better reflecting human physiological conditions in the bone marrow. Further on, maintenance of $\mathrm{CD}_{3} 4^{+}$hematopoietic stem and progenitor cells as well as engraftment levels were improved. As a side effect of gene replacement, thrombocytopenia developed. Since thrombopoeitin is crucial for platelet development, reduced levels or an altered biological activity of the humanized variant were not sufficient to contribute to thrombopoiesis in the xenogenic model system. ${ }^{155}$

Considering the mismatch of MHC molecules on mice and human immune cells, a severe response in the form of a xenogenic graft-versus-host disease can develop. It results from the action of cytotoxic T-cells directed against mouse MHC molecules. This mismatch in MHC molecules, further on, contributes to an impaired T-cell function as well as limited immunoglobulin class switching by human B-cells. To overcome these problems, mice transgenic for the human leukocyte antigen (HLA) were generated. For instance, transgenic

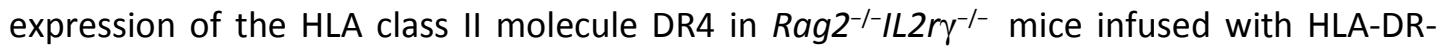
matching HSC favored homing and development of T-cell precursors in thymus, promoted further T-cell repopulation in the periphery, and developed functional CD4 and CD8 T-cells. Moreover, those mice developed functional B-cells able to reconstitute immunoglobulin $\mathrm{M}$ levels com- parable to humans and to undergo immunoglobulin class switching. ${ }^{156}$

Besides the achievements gained in the last years, several limitations of the nextgeneration humanized mice still exist. Firstly, the expression of human immune factors in immunodeficient mice has the disadvantage that many human factors cross-react with mouse cells with the possible consequence of unexpected phenotypic changes. ${ }^{157}$ Secondly, lymphoid reconstitution in engrafted mice is challenging. Even though the mesenteric lymph nodes develop, the organization and size of the peripheral lymph nodes is less sufficient. ${ }^{158,159}$

A further impairment of the humanized mouse is the inability of human granulocytes, platelets, and red blood cells to circulate appropriately in the peripheral blood of the murine host, although progenitors of these cells are detected in bone marrow. It is assumed that circulating human cells are removed by murine macrophages. In humanized mice, the administration of granulocyte colony-stimulating factor led to an improved mobilization of mature human neutrophils into peripheral blood. Subsequent LPS administration resulted in a robust neutrophil effector function in vitro. ${ }^{160}$ In another study, the in vivo administration of granulocyte colony-stimulating factor led to an enhanced circulation of human myeloid cells. ${ }^{161}$ However, the number of neutrophils detected in both studies in the periphery is still not comparable to human physiological conditions.

In recent years, multiple approaches were developed to construct a humanized mouse model. This enables researchers to penetrate much deeper into specific human pathologies and to create more detailed models for diseases. ${ }^{153,162,163}$ Although these approaches were mainly directed to evaluate details of the adaptive immune system, their further 
improvement will also include studies on human innate cells. Nevertheless, it becomes obvious that these studies are useful to investigate a clear mechanistic question rather than to examine the complete human immune system. ${ }^{152,154}$

\section{CONCLUSIONS}

After being divided about 90 million years ago, independent development started for the mouse and human lineages. Organization of the immune system differs considerably between both species. The considerably longer lifespan of man versus mouse is assumed to be a trigger to ensure an efficient control over pathogens by the human immune system. In defense against invading microorganisms, resistance mechanisms dominate in humans, while tolerance determines the immune response in mice. ${ }^{12,13}$ Species differences exist in activation and function of effector molecules released by immune cells to control pathogens. Accordingly, the human immune system is highly susceptible to Toll-like receptor agonists in contrast to the murine system. ${ }^{17}$ Different pathways are also initiated in response to IFN $\gamma$. In man, tryptophan depletion via enhanced expression of IDO is induced by IFN $\gamma$, while IRG proteins are expressed and autophagy of pathogen-loaded cells is induced in mice. ${ }^{24}$ Furthermore, a number of pathogens are predominantly found in humans but not, or seldom, in mice. To these pathogens belong Mycobacterium tuberculosis, Mycobacterium leprae, Shigella flexneri, Plasmodium falciparum, and viruses such as measles and dengue virus. ${ }^{65}$ Importantly, a common strategy against pathogens, traumata, and antigens can be evaluated in humans but not in mice. ${ }^{15}$

Different strategies in immune response are also reflected in the composition and properties of leukocytes. A higher number of neutrophils are characteristic of human blood. These neutrophils contain more antimicrobial components than murine cells. Activated murine macrophages enhance considerably the expression of inducible NO-synthase and arginase, a property that is only scarcely found in human macrophages. Histamine is released from human mast cells, while serotonin is liberated from these cells in mice.

Several consequences arise from the existence of different principal mechanisms to combat infections in man and mouse blood. In humans, sepsis and autoimmune disorders might develop and lead to numerous complications. It is very hard to induce such disease scenarios in more tolerant mice. Here it is necessary to provide additional genetic manipulations to alter host response and to induce secondary inflammation. Thus, the value of mice models for human diseases with inflammatory pathogenesis is limited. Drugs are known to act mostly via distinct molecular mechanisms. Thus, investigation by animal models is mainly directed to evaluate these mechanisms. As the main immune mechanisms in mice are quite different to humans, it is necessary to develop synthetic human models for investigations of disease-mediated alterations in cells and tissues as well as to extract information from personal genomes.

Taken together, these differences in organization of the immune system greatly disturb direct translation of data from murine disease models to human pathologies. Thus, it is not surprising that in many cases promising therapeutic principles found in mice models do not work in humans. In each case, it must be carefully considered which individual aspects can be similarly reflected in both species and where differences in pathways, protein expression, sensitivity of initiating agents, and others make a direct translation impossible. 


\section{Acknowledgments}

The authors gratefully acknowledge the financial support provided by the Sächsische Aufbaubank from a funding of the European Regional Development Fund (ERDF) (SAB Project no. 100116526) and the German Federal Ministry of Education and Research (BMBF 1315883). 


\section{Figure and Tables}

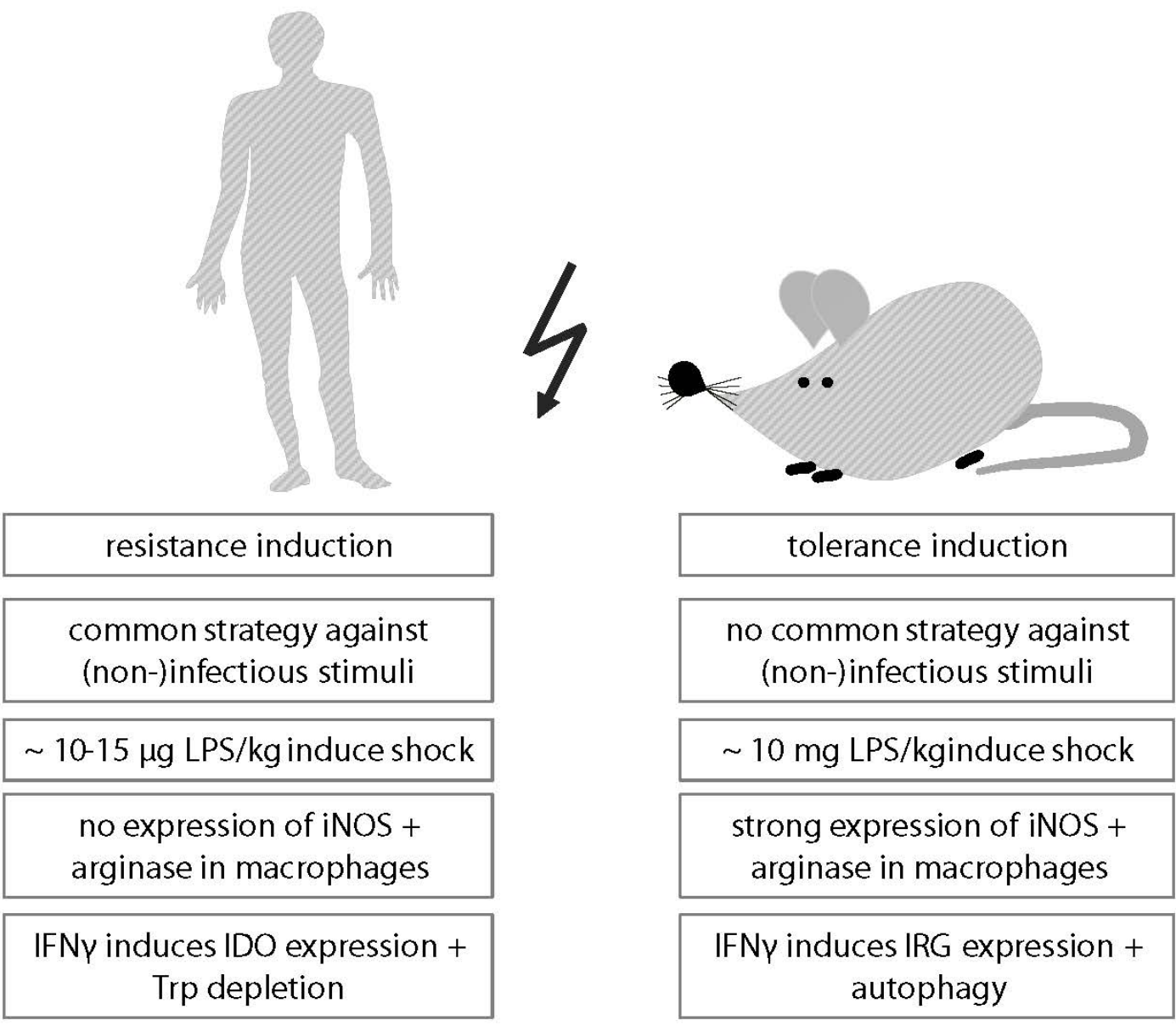

Figure 1: Important differences between mouse and man in immunological defense strategies.

Table 1: Main differences between human and mouse genomes ${ }^{10}$

\begin{tabular}{lcc}
\hline \multicolumn{1}{c}{ Genome characteristics } & Humans & Mice \\
\hline Number of genes & 19,042 & 20,21 \\
\hline Functionally related genes & 15,187 & 15,18 \\
\hline Percentage of orthologous genes & $80 \%$ & $75 \%$ \\
\hline Gene duplicates & 2941 & 376 \\
\hline
\end{tabular}


Table 2: Differences in Toll-like receptor properties and signaling between man and mouse

\begin{tabular}{|c|c|c|c|c|}
\hline Receptor & Property & Humans & Mice & Ref. \\
\hline TLR2 & $\begin{array}{c}\text { Expression in thymus and } \\
\text { T-cells }\end{array}$ & No & Yes & 164 \\
\hline TLR2 & $\begin{array}{l}\text { Expression on circulating } \\
\text { leukocytes }\end{array}$ & Expressed & Poorly expressed & 164 \\
\hline TLR2 & $\begin{array}{c}\text { Recognition of } \\
\text { Aspergillus fumigatus by } \\
\text { heterodimers with other } \\
\text { TLRs }\end{array}$ & $\begin{array}{l}\text { Heterodimers with TRL1, } \\
\text { but not TRL6 }\end{array}$ & $\begin{array}{l}\text { Heterodimers with TRL1 } \\
\text { and TRL6 }\end{array}$ & 165 \\
\hline TLR2 & $\begin{array}{c}\text { Recognition of tri- } \\
\text { lauroylated lipopeptides }\end{array}$ & No & Yes & 166 \\
\hline TLR3 & $\begin{array}{l}\text { Stimulation of dendritic } \\
\text { cells and macrophages by } \\
\text { polyinosinic-polycytidylic } \\
\text { acid }\end{array}$ & $\begin{array}{l}\text { No activation of NFKB and } \\
\text { MAPK; no production of } \\
\text { TNF } \alpha \text { and IL-6 }\end{array}$ & $\begin{array}{l}\text { Activation of NFKB and } \\
\text { MAPK; production of } \\
\text { TNF } \alpha \text { and IL-6 }\end{array}$ & 167 \\
\hline TLR3 & Effect of LPS and IFN $\beta$ & $\begin{array}{l}\text { LPS prevents IFN } \beta \text {-mediated } \\
\text { upregulation of TLR3 }\end{array}$ & $\begin{array}{c}\text { LPS mediates upregulation } \\
\text { of TLR3 via IFN } \beta\end{array}$ & 168 \\
\hline TLR4 & $\begin{array}{l}\text { Recognition of taxol or } \\
\text { LPS from Leptospira }\end{array}$ & No & Yes & 169,170 \\
\hline TLR4 & Cytotoxic effects of LPS & At low doses & At high doses & $17,18,19-23$ \\
\hline TLR5 & Recognition of flagellins & & $\begin{array}{c}\text { More sensitive against } \\
\text { most flagellins compared } \\
\text { to human TLR5 }\end{array}$ & 171 \\
\hline TLR7/8 & $\begin{array}{l}\text { Activation by single- } \\
\text { stranded RNA }\end{array}$ & By TLR8 & By TLR7 & 172 \\
\hline TLR8 & $\begin{array}{l}\text { Activation by antiviral } \\
\text { compound R848 }\end{array}$ & Yes & No & 173 \\
\hline TLR10 & $\begin{array}{l}\text { Response to viral } \\
\text { components }\end{array}$ & Yes & Pseudogene & 174 \\
\hline TLR11 & Recognition of profilin & Pseudogene & Yes & 175 \\
\hline TLR12 & Recognition of profilin & Gene not present & Yes & 175 \\
\hline TLR13 & & Gene not present & & 176 \\
\hline
\end{tabular}

Table 3: Differences in expression and properties of granule constituents in neutrophils in man and mouse

\begin{tabular}{lccc}
\hline Granule expression of & Humans & Mouse & Ref. \\
\hline Defensins & Strong & Absent & 48,49 \\
\hline BPI & Strong & Poor & 55 \\
\hline MPO & Strong & Poor & 56,57 \\
\hline$\beta$-Glucuronidase & Strong & Poor & 57 \\
\hline Lysozyme & Strong & Poor & 57 \\
\hline Alkaline phosphatase & Strong & Poor & 57 \\
\hline Arginase type-1 & Constitutively & Only after stimulation & 76 \\
\hline
\end{tabular}




\section{References}

(1) Russell ES. A history of mouse genetics. Annu Rev Genet. 1985;19:1-28.

(2) Poltorak A, He X, Smirnova I, Liu MY, Van HC, Du X, Birdwell D, Alejos E, Silva M, Galanos C, Freudenberg M, Ricciardi-Castagnoli P, Layton B, Beutler B. Defective LPS signaling in C3H/HeJ and C57BL/10ScCr mice: mutations in Tlr4 gene. Science. 1998;282:2085-8.

(3) Beutler B. TIr4: central component of the sole mammalian LPS sensor. Curr Opin Immunol. 2000;12:20-6.

(4) Beutler B. Innate immunity: an overview. Mol Immunol. 2004;40:845-59.

(5) Sander S, Calado DP, Srinivasan L, Kochert K, Zhang B, Rosolowski M, Rodig SJ, Holzmann K, Stilgenbauer S, Siebert R, Bullinger L, Rajewsky K. Synergy between PI3K signaling and MYC in Burkitt lymphomagenesis. Cancer Cell. 2012;22:167-79.

(6) Etzioni A. Genetic etiologies of leukocyte adhesion defects. Curr Opin Immunol. 2009;21:481-6.

(7) Davis MM. A prescription for human immunology. Immunity. 2008;29:835-8.

(8) Jin HK, Yamashita T, Ochiai K, Haller O, Watanabe T. Characterization and expression of the Mx1 gene in wild mouse species. Biochem Genet. 1998;36:311-22.

(9) Waterston RH, Lindblad-Toh K, Birney E, Rogers J, Abril JF, Agarwal P, Agarwala R, Ainscough R, Alexandersson M, An P, Antonarakis SE, Attwood J, Baertsch R, Bailey J, Barlow K, Beck S, Berry E, Birren B, Bloom T, Bork P, Botcherby M, Bray N, Brent MR, Brown DG, Brown SD, Bult C, Burton J, Butler J, Campbell RD, Carninci P, Cawley S, Chiaromonte F, Chinwalla AT, Church DM, Clamp M, Clee C, Collins FS, Cook LL, Copley RR, Coulson A, Couronne O, Cuff J, Curwen V, Cutts T, Daly M, David R, Davies J, Delehaunty KD, Deri J, Dermitzakis ET, Dewey C, Dickens NJ, Diekhans M, Dodge S, Dubchak I, Dunn DM, Eddy SR, Elnitski L, Emes RD, Eswara P, Eyras E, Felsenfeld A, Fewell GA, Flicek P, Foley K, Frankel WN, Fulton LA, Fulton RS, Furey TS, Gage D, Gibbs RA, Glusman G, Gnerre S, Goldman N, Goodstadt L, Grafham D, Graves TA, Green ED, Gregory S, Guigo R, Guyer M, Hardison RC, Haussler D, Hayashizaki Y, Hillier LW, Hinrichs A, Hlavina W, Holzer T, Hsu F, Hua A, Hubbard T, Hunt A, Jackson I, Jaffe DB, Johnson LS, Jones M, Jones TA, Joy A, Kamal M, Karlsson EK, Karolchik D, Kasprzyk A, Kawai J, Keibler E, Kells C, Kent WJ, Kirby A, Kolbe DL, Korf I, Kucherlapati RS, Kulbokas EJ, Kulp D, Landers T, Leger JP, Leonard S, Letunic I, Levine R, Li J, Li M, Lloyd C, Lucas S, Ma B, Maglott DR, Mardis ER, Matthews L, Mauceli E, Mayer JH, McCarthy M, McCombie WR, McLaren S, McLay K, McPherson JD, Meldrim J, Meredith B, Mesirov JP, Miller W, Miner TL, Mongin E, Montgomery KT, Morgan M, Mott R, Mullikin JC, Muzny DM, Nash WE, Nelson JO, Nhan MN, Nicol R, Ning Z, Nusbaum C, O'Connor MJ, Okazaki Y, Oliver K, Overton-Larty E, Pachter L, Parra G, Pepin KH, Peterson J, Pevzner P, Plumb R, Pohl CS, Poliakov A, Ponce TC, Ponting CP, Potter S, Quail M, Reymond A, Roe BA, Roskin KM, Rubin EM, Rust AG, Santos R, Sapojnikov V, Schultz B, Schultz J, Schwartz MS, Schwartz S, Scott C, Seaman S, Searle S, Sharpe T, Sheridan A, Shownkeen R, Sims S, Singer JB, Slater G, Smit A, Smith DR, Spencer B, Stabenau A, Stange-Thomann N, Sugnet C, Suyama M, Tesler G, Thompson J, Torrents D, Trevaskis E, Tromp J, Ucla C, UretaVidal A, Vinson JP, Von Niederhausern AC, Wade CM, Wall M, Weber RJ, Weiss RB, Wendl MC, West AP, Wetterstrand K, Wheeler R, Whelan S, Wierzbowski J, Willey D, Williams S, Wilson RK, Winter E, Worley KC, Wyman D, Yang S, Yang SP, Zdobnov EM, Zody MC, Lander ES. Initial sequencing and comparative analysis of the mouse genome. Nature. 2002;420:520-62.

(10) Church DM, Goodstadt L, Hillier LW, Zody MC, Goldstein S, She X, Bult CJ, Agarwala R, Cherry JL, DiCuccio M, Hlavina W, Kapustin Y, Meric P, Maglott D, Birtle Z, Marques AC, Graves T, Zhou S, Teague B, Potamousis K, Churas C, Place M, Herschleb J, Runnheim R, Forrest D, Amos-Landgraf J, Schwartz DC, Cheng Z, Lindblad-Toh K, Eichler EE, Ponting CP. Lineage-specific biology revealed by a finished genome assembly of the mouse. PLoS Biol. 2009;7:e1000112.

(11) Liao BY, Zhang J. Null mutations in human and mouse orthologs frequently result in different phenotypes. Proc Natl Acad Sci U S A. 2008;105:6987-92.

(12) Raberg L, Sim D, Read AF. Disentangling genetic variation for resistance and tolerance to infectious diseases in animals. Science. 2007;318:812-4.

(13) Schneider DS, Ayres JS. Two ways to survive infection: what resistance and tolerance can teach us about treating infectious diseases. Nat Rev Immunol. 2008;8:889-95.

(14) Akira S, Takeda K. Toll-like receptor signalling. Nat Rev Immunol. 2004;4:499-511. 
(15) Seok J, Warren HS, Cuenca AG, Mindrinos MN, Baker HV, Xu W, Richards DR, McDonald-Smith GP, Gao $H$, Hennessy L, Finnerty CC, Lopez CM, Honari S, Moore EE, Minei JP, Cuschieri J, Bankey PE, Johnson JL, Sperry J, Nathens AB, Billiar TR, West MA, Jeschke MG, Klein MB, Gamelli RL, Gibran NS, Brownstein BH, Miller-Graziano C, Calvano SE, Mason PH, Cobb JP, Rahme LG, Lowry SF, Maier RV, Moldawer LL, Herndon DN, Davis RW, Xiao W, Tompkins RG. Genomic responses in mouse models poorly mimic human inflammatory diseases. Proc Natl Acad Sci U S A. 2013;110:3507-12.

(16) Chen JY, Qiao Y, Komisar JL, Baze WB, Hsu IC, Tseng J. Increased susceptibility to staphylococcal enterotoxin B intoxication in mice primed with actinomycin D. Infect Immun. 1994;62:4626-31.

(17) Warren HS, Fitting C, Hoff E, Adib-Conquy M, Beasley-Topliffe L, Tesini B, Liang X, Valentine C, Hellman J, Hayden D, Cavaillon JM. Resilience to bacterial infection: difference between species could be due to proteins in serum. J Infect Dis. 2010;201:223-32.

(18) van der Poll T, Van Zee KJ, Endert E, Coyle SM, Stiles DM, Pribble JP, Catalano MA, Moldawer LL, Lowry SF. Interleukin-1 receptor blockade does not affect endotoxin-induced changes in plasma thyroid hormone and thyrotropin concentrations in man. J Clin Endocrinol Metab. 1995;80:1341-6.

(19) Martich GD, Danner RL, Ceska M, Suffredini AF. Detection of interleukin 8 and tumor necrosis factor in normal humans after intravenous endotoxin: the effect of antiinflammatory agents. J Exp Med. 1991;173:1021-4.

(20) Taveira da Silva AM, Kaulbach HC, Chuidian FS, Lambert DR, Suffredini AF, Danner RL. Brief report: shock and multiple-organ dysfunction after self-administration of Salmonella endotoxin. N Engl J Med. 1993;328:145760.

(21) Sauter C, Wolfensberger C. Interferon in human serum after injection of endotoxin. Lancet. 1980;2:8523.

(22) Glode LM, Mergenhagen SE, Rosenstreich DL. Significant contribution of spleen cells in mediating the lethal effects of endotoxin in vivo. Infect Immun. 1976;14:626-30.

(23) Reynolds K, Novosad B, Hoffhines A, Gipson J, Johnson J, Peters J, Gonzalez F, Gimble J, Hill M. Pretreatment with troglitazone decreases lethality during endotoxemia in mice. J Endotoxin Res. 2002;8:307-14.

(24) Coers J, Starnbach MN, Howard JC. Modeling infectious disease in mice: co-adaptation and the role of host-specific IFNgamma responses. PLoS Pathog. 2009;5:e1000333.

(25) Gutierrez MG, Master SS, Singh SB, Taylor GA, Colombo MI, Deretic V. Autophagy is a defense mechanism inhibiting BCG and Mycobacterium tuberculosis survival in infected macrophages. Cell. 2004;119:75366.

(26) Deretic V. Autophagy in innate and adaptive immunity. Trends Immunol. 2005;26:523-8.

(27) Singh SB, Davis AS, Taylor GA, Deretic V. Human IRGM induces autophagy to eliminate intracellular mycobacteria. Science. 2006;313:1438-41.

(28) Martens S, Parvanova I, Zerrahn J, Griffiths G, Schell G, Reichmann G, Howard JC. Disruption of Toxoplasma gondii parasitophorous vacuoles by the mouse p47-resistance GTPases. PLoS Pathog. 2005;1:e24.

(29) Al-Zeer MA, Al-Younes HM, Braun PR, Zerrahn J, Meyer TF. IFN-gamma-inducible Irga6 mediates host resistance against Chlamydia trachomatis via autophagy. PLoS One. 2009;4:e4588.

(30) Roshick C, Wood H, Caldwell HD, McClarty G. Comparison of gamma interferon-mediated antichlamydial defense mechanisms in human and mouse cells. Infect Immun. 2006;74:225-38.

(31) Doeing DC, Borowicz JL, Crockett ET. Gender dimorphism in differential peripheral blood leukocyte counts in mice using cardiac, tail, foot, and saphenous vein puncture methods. BMC Clin Pathol. 2003;3:3.

(32) Haley PJ. Species differences in the structure and function of the immune system. Toxicology. 2003;188:49-71.

(33) Arnhold J, Flemmig J. Human myeloperoxidase in innate and acquired immunity. Arch Biochem Biophys. 2010;500:92-106.

(34) Zlotnik A, Yoshie O, Nomiyama H. The chemokine and chemokine receptor superfamilies and their molecular evolution. Genome Biol. 2006;7:243.

(35) Rossi DL, Hurst SD, Xu Y, Wang W, Menon S, Coffman RL, Zlotnik A. Lungkine, a novel CXC chemokine, specifically expressed by lung bronchoepithelial cells. J Immunol. 1999;162:5490-7. 
(36) Hol J, Wilhelmsen L, Haraldsen G. The murine IL-8 homologues KC, MIP-2, and LIX are found in endothelial cytoplasmic granules but not in Weibel-Palade bodies. J Leukoc Biol. 2010;87:501-8.

(37) Durstin M, Gao JL, Tiffany HL, McDermott D, Murphy PM. Differential expression of members of the Nformylpeptide receptor gene cluster in human phagocytes. Biochem Biophys Res Commun. 1994;201:174-9.

(38) Gao JL, Chen H, Filie JD, Kozak CA, Murphy PM. Differential expansion of the N-formylpeptide receptor gene cluster in human and mouse. Genomics. 1998;51:270-6.

(39) Hartt JK, Barish G, Murphy PM, Gao JL. N-formylpeptides induce two distinct concentration optima for mouse neutrophil chemotaxis by differential interaction with two $\mathrm{N}$-formylpeptide receptor (FPR) subtypes. Molecular characterization of FPR2, a second mouse neutrophil FPR. J Exp Med. 1999;190:741-7.

(40) Mandal P, Novotny M, Hamilton TA. Lipopolysaccharide induces formyl peptide receptor 1 gene expression in macrophages and neutrophils via transcriptional and posttranscriptional mechanisms. J Immunol. 2005;175:6085-91.

(41) Wang ZG, Ye RD. Characterization of two new members of the formyl peptide receptor gene family from 12956 mice. Gene. 2002;299:57-63.

(42) Takano T, Fiore S, Maddox JF, Brady HR, Petasis NA, Serhan CN. Aspirin-triggered 15-epi-lipoxin A4 (LXA4) and LXA4 stable analogues are potent inhibitors of acute inflammation: evidence for anti-inflammatory receptors. J Exp Med. 1997;185:1693-704.

(43) Zollner O, Lenter MC, Blanks JE, Borges E, Steegmaier M, Zerwes HG, Vestweber D. L-selectin from human, but not from mouse neutrophils binds directly to E-selectin. J Cell Biol. 1997;136:707-16.

(44) Kobzdej MM, Leppanen A, Ramachandran V, Cummings RD, McEver RP. Discordant expression of selectin ligands and sialyl Lewis x-related epitopes on murine myeloid cells. Blood. 2002;100:4485-94.

(45) Bochner BS, Sterbinsky SA, Bickel CA, Werfel S, Wein M, Newman W. Differences between human eosinophils and neutrophils in the function and expression of sialic acid-containing counterligands for E-selectin. J Immunol. 1994;152:774-82.

(46) Nimrichter L, Burdick MM, Aoki K, Laroy W, Fierro MA, Hudson SA, Von Seggern CE, Cotter RJ, Bochner BS, Tiemeyer M, Konstantopoulos K, Schnaar RL. E-selectin receptors on human leukocytes. Blood. 2008;112:3744-52.

(47) Mondal N, Buffone A, Jr., Neelamegham S. Distinct glycosyltransferases synthesize E-selectin ligands in human vs. mouse leukocytes. Cell Adh Migr. 2013;7:288-92.

(48) Lehrer RI, Lichtenstein AK, Ganz T. Defensins: antimicrobial and cytotoxic peptides of mammalian cells. Annu Rev Immunol. 1993;11:105-28.

(49) Eisenhauer PB, Lehrer RI. Mouse neutrophils lack defensins. Infect Immun. 1992;60:3446-7.

(50) Shanahan MT, Tanabe H, Ouellette AJ. Strain-specific polymorphisms in Paneth cell alpha-defensins of C57BL/6 mice and evidence of vestigial myeloid alpha-defensin pseudogenes. Infect Immun. 2011;79:459-73.

(51) Ghosh D, Porter E, Shen B, Lee SK, Wilk D, Drazba J, Yadav SP, Crabb JW, Ganz T, Bevins CL. Paneth cell trypsin is the processing enzyme for human defensin-5. Nat Immunol. 2002;3:583-90.

(52) Wilson CL, Ouellette AJ, Satchell DP, Ayabe T, Lopez-Boado YS, Stratman JL, Hultgren SJ, Matrisian LM, Parks WC. Regulation of intestinal alpha-defensin activation by the metalloproteinase matrilysin in innate host defense. Science. 1999;286:113-7.

(53) Canny G, Levy O. Bactericidal/permeability-increasing protein (BPI) and BPI homologs at mucosal sites. Trends Immunol. 2008;29:541-7.

(54) Egesten A, Breton-Gorius J, Guichard J, Gullberg U, Olsson I. The heterogeneity of azurophil granules in neutrophil promyelocytes: immunogold localization of myeloperoxidase, cathepsin G, elastase, proteinase 3 , and bactericidal/permeability increasing protein. Blood. 1994;83:2985-94.

(55) Lennartsson A, Pieters K, Vidovic K, Gullberg U. A murine antibacterial ortholog to human bactericidal/permeability-increasing protein (BPI) is expressed in testis, epididymis, and bone marrow. J Leukoc Biol. 2005;77:369-77. 
(56) Noguchi N, Nakano K, Aratani Y, Koyama H, Kodama T, Niki E. Role of myeloperoxidase in the neutrophilinduced oxidation of low density lipoprotein as studied by myeloperoxidase-knockout mouse. J Biochem. 2000;127:971-6.

(57) Rausch PG, Moore TG. Granule enzymes of polymorphonuclear neutrophils: A phylogenetic comparison. Blood. 1975;46:913-9.

(58) Zhao WG, Lu JP, Regmi A, Austin GE. Identification and functional analysis of multiple murine myeloperoxidase (MPO) promoters and comparison with the human MPO promoter region. Leukemia. 1997;11:97-105.

(59) Shamri R, Xenakis JJ, Spencer LA. Eosinophils in innate immunity: an evolving story. Cell Tissue Res. 2011;343:57-83.

(60) Lee JJ, Jacobsen EA, Ochkur SI, McGarry MP, Condjella RM, Doyle AD, Luo H, Zellner KR, Protheroe CA, Willetts L, Lesuer WE, Colbert DC, Helmers RA, Lacy P, Moqbel R, Lee NA. Human versus mouse eosinophils: "that which we call an eosinophil, by any other name would stain as red". J Allergy Clin Immunol. 2012;130:572-84.

(61) Provost V, Larose MC, Langlois A, Rola-Pleszczynski M, Flamand N, Laviolette M. CCL26/eotaxin-3 is more effective to induce the migration of eosinophils of asthmatics than CCL11/eotaxin-1 and CCL24/eotaxin-2. J Leukoc Biol. 2013;94:213-22.

(62) Komiya A, Nagase H, Yamada H, Sekiya T, Yamaguchi M, Sano Y, Hanai N, Furuya A, Ohta K, Matsushima K, Yoshie O, Yamamoto K, Hirai K. Concerted expression of eotaxin-1, eotaxin-2, and eotaxin-3 in human bronchial epithelial cells. Cell Immunol. 2003;225:91-100.

(63) Borchers MT, Ansay T, DeSalle R, Daugherty BL, Shen H, Metzger M, Lee NA, Lee JJ. In vitro assessment of chemokine receptor-ligand interactions mediating mouse eosinophil migration. J Leukoc Biol. 2002;71:1033-41.

(64) Mosser DM, Edwards JP. Exploring the full spectrum of macrophage activation. Nat Rev Immunol. 2008;8:958-69.

(65) Murray PJ, Wynn TA. Protective and pathogenic functions of macrophage subsets. Nat Rev Immunol. 2011;11:723-37.

(66) Martinez FO, Gordon S, Locati M, Mantovani A. Transcriptional profiling of the human monocyte-tomacrophage differentiation and polarization: new molecules and patterns of gene expression. J Immunol. 2006;177:7303-11.

(67) Barish GD, Downes M, Alaynick WA, Yu RT, Ocampo CB, Bookout AL, Mangelsdorf DJ, Evans RM. A Nuclear Receptor Atlas: macrophage activation. Mol Endocrinol. 2005;19:2466-77.

(68) Schneemann M, Schoeden G. Macrophage biology and immunology: man is not a mouse. J Leukoc Biol. 2007;81:579.

(69) Schneemann M, Schoedon G. Species differences in macrophage NO production are important. Nat Immunol. 2002;3:102.

(70) Denis M. Human monocytes/macrophages: NO or no NO? J Leukoc Biol. 1994;55:682-4.

(71) MacMicking J, Xie QW, Nathan C. Nitric oxide and macrophage function. Annu Rev Immunol. 1997;15:323-50.

(72) Weinberg JB. Nitric oxide production and nitric oxide synthase type 2 expression by human mononuclear phagocytes: a review. Mol Med. 1998;4:557-91.

(73) Fang FC, Nathan CF. Man is not a mouse: reply. J Leukoc Biol. 2007;81:580.

(74) Munder M, Eichmann K, Modolell M. Alternative metabolic states in murine macrophages reflected by the nitric oxide synthase/arginase balance: competitive regulation by CD4+ T cells correlates with Th1/Th2 phenotype. J Immunol. 1998;160:5347-54.

(75) Stempin CC, Dulgerian LR, Garrido VV, Cerban FM. Arginase in parasitic infections: macrophage activation, immunosuppression, and intracellular signals. J Biomed Biotechnol. 2010;2010:683485.

(76) Munder M, Mollinedo F, Calafat J, Canchado J, Gil-Lamaignere C, Fuentes JM, Luckner C, Doschko G, Soler G, Eichmann K, Muller FM, Ho AD, Goerner M, Modolell M. Arginase I is constitutively expressed in human granulocytes and participates in fungicidal activity. Blood. 2005;105:2549-56. 
(77) Ochoa JB, Bernard AC, O'Brien WE, Griffen MM, Maley ME, Rockich AK, Tsuei BJ, Boulanger BR, Kearney PA, Morris Jr SMJ. Arginase I expression and activity in human mononuclear cells after injury. Ann Surg. 2001;233:393-9.

(78) Raes G, Brys L, Dahal BK, Brandt J, Grooten J, Brombacher F, Vanham G, Noel W, Bogaert P, Boonefaes T, Kindt A, Van den Bergh R, Leenen PJ, De BP, Ghassabeh GH. Macrophage galactose-type C-type lectins as novel markers for alternatively activated macrophages elicited by parasitic infections and allergic airway inflammation. J Leukoc Biol. 2005;77:321-7.

(79) Nathan C, Shiloh MU. Reactive oxygen and nitrogen intermediates in the relationship between mammalian hosts and microbial pathogens. Proc Natl Acad Sci U S A. 2000;97:8841-8.

(80) Mouy R, Fischer A, Vilmer E, Seger R, Griscelli C. Incidence, severity, and prevention of infections in chronic granulomatous disease. J Pediatr. 1989;114:555-60.

(81) Jackson SH, Gallin JI, Holland SM. The p47phox mouse knock-out model of chronic granulomatous disease. J Exp Med. 1995;182:751-8.

(82) Gaut JP, Yeh GC, Tran HD, Byun J, Henderson JP, Richter GM, Brennan ML, Lusis AJ, Belaaouaj A, Hotchkiss RS, Heinecke JW. Neutrophils employ the myeloperoxidase system to generate antimicrobial brominating and chlorinating oxidants during sepsis. Proc Natl Acad Sci U S A. 2001;98:11961-6.

(83) Brennan ML, Anderson MM, Shih DM, Qu XD, Wang X, Mehta AC, Lim LL, Shi W, Hazen SL, Jacob JS, Crowley JR, Heinecke JW, Lusis AJ. Increased atherosclerosis in myeloperoxidase-deficient mice. J Clin Invest. 2001;107:419-30.

(84) Aratani Y, Kura F, Watanabe H, Akagawa H, Takano Y, Ishida-Okawara A, Suzuki K, Maeda N, Koyama H. Contribution of the myeloperoxidase-dependent oxidative system to host defence against Cryptococcus neoformans. J Med Microbiol. 2006;55:1291-9.

(85) Lehrer RI, Cline MJ. Leukocyte myeloperoxidase deficiency and disseminated candidiasis: the role of myeloperoxidase in resistance to Candida infection. J Clin Invest. 1969;48:1478-88.

(86) Nauseef WM. The proper study of mankind. J Clin Invest. 2001;107:401-3.

(87) Shiloh MU, MacMicking JD, Nicholson S, Brause JE, Potter S, Marino M, Fang F, Dinauer M, Nathan C. Phenotype of mice and macrophages deficient in both phagocyte oxidase and inducible nitric oxide synthase. Immunity. 1999;10:29-38.

(88) Trinchieri G, Perussia B. Human natural killer cells: biologic and pathologic aspects. Lab Invest. 1984;50:489-513.

(89) Colucci F, Di Santo JP, Leibson PJ. Natural killer cell activation in mice and men: different triggers for similar weapons? Nat Immunol. 2002;3:807-13.

(90) Lanier LL. NK cell receptors. Annu Rev Immunol. 1998;16:359-93.

(91) Kushnir-Sukhov NM, Brown JM, Wu Y, Kirshenbaum A, Metcalfe DD. Human mast cells are capable of serotonin synthesis and release. J Allergy Clin Immunol. 2007;119:498-9.

(92) Bischoff SC. Role of mast cells in allergic and non-allergic immune responses: comparison of human and murine data. Nat Rev Immunol. 2007;7:93-104.

(93) Ohta Y, Nishikimi M. Random nucleotide substitutions in primate nonfunctional gene for L-gulonogamma-lactone oxidase, the missing enzyme in L-ascorbic acid biosynthesis. Biochim Biophys Acta. 1999;1472:408-11.

(94) Iwama M, Amano A, Shimokado K, Maruyama N, Ishigami A. Ascorbic acid levels in various tissues, plasma and urine of mice during aging. J Nutr Sci Vitaminol (Tokyo). 2012;58:169-74.

(95) Michels AJ, Hagen TM, Frei B. Human genetic variation influences vitamin C homeostasis by altering vitamin C transport and antioxidant enzyme function. Annu Rev Nutr. 2013;33:45-70.

(96) Montel-Hagen A, Kinet S, Manel N, Mongellaz C, Prohaska R, Battini JL, Delaunay J, Sitbon M, Taylor N. Erythrocyte Glut1 triggers dehydroascorbic acid uptake in mammals unable to synthesize vitamin C. Cell. 2008;132:1039-48.

(97) May JM. Ascorbate function and metabolism in the human erythrocyte. Front Biosci. 1998;3:d1-10. 
(98) May JM, Qu Z, Morrow JD. Mechanisms of ascorbic acid recycling in human erythrocytes. Biochim Biophys Acta. 2001;1528:159-66.

(99) Peterkofsky B. Ascorbate requirement for hydroxylation and secretion of procollagen: relationship to inhibition of collagen synthesis in scurvy. Am J Clin Nutr. 1991;54:1135S-40S.

(100) Hulse JD, Ellis SR, Henderson LM. Carnitine biosynthesis. beta-Hydroxylation of trimethyllysine by an alpha-ketoglutarate-dependent mitochondrial dioxygenase. J Biol Chem. 1978;253:1654-9.

(101) Diliberto EJ, Jr., Daniels AJ, Viveros OH. Multicompartmental secretion of ascorbate and its dual role in dopamine beta-hydroxylation. Am J Clin Nutr. 1991;54:1163S-72S.

(102) Hochstein P, Hatch L, Sevanian A. Uric acid: functions and determination. Meth Enzymol. 1984;105:1626.

(103) Nyyssonen K, Porkkala-Sarataho E, Kaikkonen J, Salonen JT. Ascorbate and urate are the strongest determinants of plasma antioxidative capacity and serum lipid resistance to oxidation in Finnish men. Atherosclerosis. 1997;130:223-33.

(104) Wu X, Wakamiya M, Vaishnav S, Geske R, Montgomery C, Jr., Jones P, Bradley A, Caskey CT. Hyperuricemia and urate nephropathy in urate oxidase-deficient mice. Proc Natl Acad Sci U S A. 1994;91:742-6.

(105) Ramazzina I, Folli C, Secchi A, Berni R, Percudani R. Completing the uric acid degradation pathway through phylogenetic comparison of whole genomes. Nat Chem Biol. 2006;2:144-8.

(106) Wu XW, Lee CC, Muzny DM, Caskey CT. Urate oxidase: primary structure and evolutionary implications. Proc Natl Acad Sci U S A. 1989;86:9412-6.

(107) Alvarez-Lario B, Macarron-Vicente J. Uric acid and evolution. Rheumatology. 2010;49:2010-5.

(108) Huijbers IJ, Bin AR, Pritchard C, Cozijnsen M, Kwon MC, Proost N, Song JY, de VH, Badhai J, Sutherland K, Krimpenfort P, Michalak EM, Jonkers J, Berns A. Rapid target gene validation in complex cancer mouse models using re-derived embryonic stem cells. EMBO Mol Med. 2014;6:212-25.

(109) Jo D, Nashabi A, Doxsee C, Lin Q, Unutmaz D, Chen J, Ruley HE. Epigenetic regulation of gene structure and function with a cell-permeable Cre recombinase. Nat Biotechnol. 2001;19:929-33.

(110) Bagchi A, Papazoglu C, Wu Y, Capurso D, Brodt M, Francis D, Bredel M, Vogel H, Mills AA. CHD5 is a tumor suppressor at human 1p36. Cell. 2007;128:459-75.

(111) Zuber J, McJunkin K, Fellmann C, Dow LE, Taylor MJ, Hannon GJ, Lowe SW. Toolkit for evaluating genes required for proliferation and survival using tetracycline-regulated RNAi. Nat Biotechnol. 2011;29:79-83.

(112) Crawford NP, Qian X, Ziogas A, Papageorge AG, Boersma BJ, Walker RC, Lukes L, Rowe WL, Zhang J, Ambs S, Lowy DR, Anton-Culver H, Hunter KW. Rrp1b, a new candidate susceptibility gene for breast cancer progression and metastasis. PLoS Genet. 2007;3:e214.

(113) Bard-Chapeau EA, Nguyen AT, Rust AG, Sayadi A, Lee P, Chua BQ, New LS, de JJ, Ward JM, Chin CK, Chew V, Toh HC, Abastado JP, Benoukraf T, Soong R, Bard FA, Dupuy AJ, Johnson RL, Radda GK, Chan EC, Wessels LF, Adams DJ, Jenkins NA, Copeland NG. Transposon mutagenesis identifies genes driving hepatocellular carcinoma in a chronic hepatitis B mouse model. Nat Genet. 2014;46:24-32.

(114) Kwon MC, Berns A. Mouse models for lung cancer. Mol Oncol. 2013;7:165-77.

(115) Young M, Ordonez L, Clarke AR. What are the best routes to effectively model human colorectal cancer? Mol Oncol. 2013;7:178-89.

(116) Cheon DJ, Orsulic S. Mouse models of cancer. Annu Rev Pathol. 2011;6:95-119.

(117) Hunter KW. Mouse models of cancer: does the strain matter? Nat Rev Cancer. 2012;12:144-9.

(118) Wekerle H, Flugel A, Fugger L, Schett G, Serreze D. Autoimmunity's next top models. Nat Med. 2012;18:66-70.

(119) Panitch HS, Hirsch RL, Schindler J, Johnson KP. Treatment of multiple sclerosis with gamma interferon: exacerbations associated with activation of the immune system. Neurology. 1987;37:1097-102.

(120) Lublin FD, Knobler RL, Kalman B, Goldhaber M, Marini J, Perrault M, D'Imperio C, Joseph J, Alkan SS, Korngold R. Monoclonal anti-gamma interferon antibodies enhance experimental allergic encephalomyelitis. Autoimmunity. 1993;16:267-74. 
(121) Miller DH, Khan OA, Sheremata WA, Blumhardt LD, Rice GP, Libonati MA, Willmer-Hulme AJ, Dalton CM, Miszkiel KA, O'Connor PW. A controlled trial of natalizumab for relapsing multiple sclerosis. N Engl J Med. 2003;348:15-23.

(122) Dorner T, Radbruch A, Burmester GR. B-cell-directed therapies for autoimmune disease. Nat Rev Rheumatol. 2009;5:433-41.

(123) Huang H, Benoist C, Mathis D. Rituximab specifically depletes short-lived autoreactive plasma cells in a mouse model of inflammatory arthritis. Proc Natl Acad Sci U S A. 2010;107:4658-63.

(124) Cambridge G, Leandro MJ, Edwards JC, Ehrenstein MR, Salden M, Bodman-Smith M, Webster AD. Serologic changes following B lymphocyte depletion therapy for rheumatoid arthritis. Arthritis Rheum. 2003;48:2146-54.

(125) Edwards JC, Szczepanski L, Szechinski J, Filipowicz-Sosnowska A, Emery P, Close DR, Stevens RM, Shaw T. Efficacy of B-cell-targeted therapy with rituximab in patients with rheumatoid arthritis. N Engl J Med. 2004;350:2572-81.

(126) Doi K, Leelahavanichkul A, Yuen PS, Star RA. Animal models of sepsis and sepsis-induced kidney injury. J Clin Invest. 2009;119:2868-78.

(127) Beutler B, Milsark IW, Cerami AC. Passive immunization against cachectin/tumor necrosis factor protects mice from lethal effect of endotoxin. Science. 1985;229:869-71.

(128) Fisher CJ, Jr., Agosti JM, Opal SM, Lowry SF, Balk RA, Sadoff JC, Abraham E, Schein RM, Benjamin E. Treatment of septic shock with the tumor necrosis factor receptor:Fc fusion protein. The Soluble TNF Receptor Sepsis Study Group. N Engl J Med. 1996;334:1697-702.

(129) Fisher CJ, Jr., Dhainaut JF, Opal SM, Pribble JP, Balk RA, Slotman GJ, Iberti TJ, Rackow EC, Shapiro MJ, Greenman RL, . Recombinant human interleukin 1 receptor antagonist in the treatment of patients with sepsis syndrome. Results from a randomized, double-blind, placebo-controlled trial. Phase III rhIL-1ra Sepsis Syndrome Study Group. JAMA. 1994;271:1836-43.

(130) Raven K. Rodent models of sepsis found shockingly lacking. Nat Med. 2012;18:998.

(131) Reade MC, Young JD. Of mice and men (and rats): implications of species and stimulus differences for the interpretation of studies of nitric oxide in sepsis. Br J Anaesth. 2003;90:115-8.

(132) Radermacher P, Haouzi P. A mouse is not a rat is not a man: species-specific metabolic responses to sepsis - a nail in the coffin of murine models for critical care research? ICMx. 2013;1:1-5.

(133) Larsen R, Gozzelino R, Jeney V, Tokaji L, Bozza FA, Japiassu AM, Bonaparte D, Cavalcante MM, Chora A, Ferreira A, Marguti I, Cardoso S, Sepulveda N, Smith A, Soares MP. A central role for free heme in the pathogenesis of severe sepsis. Sci Transl Med. 2010;2:51ra71.

(134) Schaer DJ, Buehler PW, Alayash Al, Belcher JD, Vercellotti GM. Hemolysis and free hemoglobin revisited: exploring hemoglobin and hemin scavengers as a novel class of therapeutic proteins. Blood. 2013;121:1276-84.

(135) Ishiguro T, Imanishi K, Suzuki I. Hemopexin levels in mice. Int J Immunopharmacol. 1984;6:241-4.

(136) Delanghe JR, Langlois MR. Hemopexin: a review of biological aspects and the role in laboratory medicine. Clin Chim Acta. 2001;312:13-23.

(137) Marsden CH, Simmonds RG. Purification of mouse haptoglobin by antibody affinity chromatography and development of an ELISA to measure serum haptoglobin levels. J Immunol Methods. 1988;108:53-9.

(138) Rother RP, Bell L, Hillmen P, Gladwin MT. The clinical sequelae of intravascular hemolysis and extracellular plasma hemoglobin: a novel mechanism of human disease. JAMA. 2005;293:1653-62.

(139) Hamelmann E, Oshiba A, Loader J, Larsen GL, Gleich G, Lee J, Gelfand EW. Antiinterleukin-5 antibody prevents airway hyperresponsiveness in a murine model of airway sensitization. Am J Respir Crit Care Med. 1997;155:819-25.

(140) Leckie MJ, ten BA, Khan J, Diamant Z, O'Connor BJ, Walls CM, Mathur AK, Cowley HC, Chung KF, Djukanovic R, Hansel TT, Holgate ST, Sterk PJ, Barnes PJ. Effects of an interleukin-5 blocking monoclonal antibody on eosinophils, airway hyper-responsiveness, and the late asthmatic response. Lancet. 2000;356:2144-8.

(141) Persson CGA. Mice are not a good model of human airway disease. Am J Respir Crit Care Med. 2002;166:6-7. 
(142) Malm-Erjefalt M, Persson CG, Erjefalt JS. Degranulation status of airway tissue eosinophils in mouse models of allergic airway inflammation. Am J Respir Cell Mol Biol. 2001;24:352-9.

(143) Denzler KL, Borchers MT, Crosby JR, Cieslewicz G, Hines EM, Justice JP, Cormier SA, Lindenberger KA, Song W, Wu W, Hazen SL, Gleich GJ, Lee JJ, Lee NA. Extensive eosinophil degranulation and peroxidase-mediated oxidation of airway proteins do not occur in a mouse ovalbumin-challenge model of pulmonary inflammation. J Immunol. 2001;167:1672-82.

(144) Daugherty A, Dunn JL, Rateri DL, Heinecke JW. Myeloperoxidase, a catalyst for lipoprotein oxidation, is expressed in human atherosclerotic lesions. J Clin Invest. 1994;94:437-44.

(145) Hazen SL, Heinecke JW. 3-Chlorotyrosine, a specific marker of myeloperoxidase-catalyzed oxidation, is markedly elevated in low density lipoprotein isolated from human atherosclerotic intima. J Clin Invest. 1997;99:2075-81.

(146) Kutter D, Devaquet P, Vanderstocken G, Paulus JM, Marchal V, Gothot A. Consequences of total and subtotal myeloperoxidase deficiency: risk or benefit ? Acta Haematol. 2000;104:10-5.

(147) Zadelaar S, Kleemann R, Verschuren L, de Vries-Van der Weij, van der Hoorn J, Princen HM, Kooistra T. Mouse models for atherosclerosis and pharmaceutical modifiers. Arterioscler Thromb Vasc Biol. 2007;27:1706-21.

(148) Grass DS, Saini U, Felkner RH, Wallace RE, Lago WJ, Young SG, Swanson ME. Transgenic mice expressing both human apolipoprotein B and human CETP have a lipoprotein cholesterol distribution similar to that of normolipidemic humans. J Lipid Res. 1995;36:1082-91.

(149) Jawien J, Nastalek P, Korbut R. Mouse models of experimental atherosclerosis. J Physiol Pharmacol. 2004;55:503-17.

(150) McMillen TS, Heinecke JW, LeBoeuf RC. Expression of human myeloperoxidase by macrophages promotes atherosclerosis in mice. Circulation. 2005;111:2798-804.

(151) Castellani LW, Chang JJ, Wang X, Lusis AJ, Reynolds WF. Transgenic mice express human MPO -463G/A alleles at atherosclerotic lesions, developing hyperlipidemia and obesity in -463G males. J Lipid Res. 2006;47:136677.

(152) Shultz LD, Brehm MA, Garcia-Martinez JV, Greiner DL. Humanized mice for immune system investigation: progress, promise and challenges. Nat Rev Immunol. 2012;12:786-98.

(153) Brehm MA, Shultz LD, Greiner DL. Humanized mouse models to study human diseases. Curr Opin Endocrinol Diabetes Obes. 2010;17:120-5.

(154) Drake AC, Chen Q, Chen J. Engineering humanized mice for improved hematopoietic reconstitution. Cell Mol Immunol. 2012;9:215-24.

(155) Rongvaux A, Willinger T, Takizawa H, Rathinam C, Auerbach W, Murphy AJ, Valenzuela DM, Yancopoulos GD, Eynon EE, Stevens S, Manz MG, Flavell RA. Human thrombopoietin knockin mice efficiently support human hematopoiesis in vivo. Proc Natl Acad Sci U S A. 2011;108:2378-83.

(156) Danner R, Chaudhari SN, Rosenberger J, Surls J, Richie TL, Brumeanu TD, Casares S. Expression of HLA class II molecules in humanized NOD.Rag1KO.IL2RgcKO mice is critical for development and function of human T and B cells. PLoS One. 2011;6:e19826.

(157) Manz MG. Human-hemato-lymphoid-system mice: opportunities and challenges. Immunity. 2007;26:537-41.

(158) Vuyyuru R, Patton J, Manser T. Human immune system mice: current potential and limitations for translational research on human antibody responses. Immunol Res. 2011;51:257-66.

(159) Lang J, Kelly M, Freed BM, McCarter MD, Kedl RM, Torres RM, Pelanda R. Studies of lymphocyte reconstitution in a humanized mouse model reveal a requirement of $T$ cells for human $B$ cell maturation. J Immunol. 2013;190:2090-101.

(160) Coughlan AM, Freeley SJ, Robson MG. Humanised mice have functional human neutrophils. J Immunol Meth. 2012;385:96-104.

(161) Tanaka S, Saito Y, Kunisawa J, Kurashima Y, Wake T, Suzuki N, Shultz LD, Kiyono H, Ishikawa F. Development of mature and functional human myeloid subsets in hematopoietic stem cell-engrafted NOD/SCID/IL2rgammaKO mice. J Immunol. 2012;188:6145-55. 
(162) Denton PW, Garcia JV. Humanized mouse models of HIV infection. AIDS Rev. 2011;13:135-48.

(163) Misharin AV, Haines GK, III, Rose S, Gierut AK, Hotchkiss RS, Perlman H. Development of a new humanized mouse model to study acute inflammatory arthritis. J TransI Med. 2012;10:190.

(164) Rehli M. Of mice and men: species variations of Toll-like receptor expression. Trends Immunol. 2002;23:375-8.

(165) Rubino I, Coste A, Le RD, Roger T, Jaton K, Boeckh M, Monod M, Latge JP, Calandra T, Bochud PY. Species-specific recognition of Aspergillus fumigatus by Toll-like receptor 1 and Toll-like receptor 6. J Infect Dis. 2012;205:944-54.

(166) Grabiec A, Meng G, Fichte S, Bessler W, Wagner H, Kirschning CJ. Human but not murine toll-like receptor 2 discriminates between tri-palmitoylated and tri-lauroylated peptides. J Biol Chem. 2004;279:48004-12.

(167) Lundberg AM, Drexler SK, Monaco C, Williams LM, Sacre SM, Feldmann M, Foxwell BM. Key differences in TLR3/poly I:C signaling and cytokine induction by human primary cells: a phenomenon absent from murine cell systems. Blood. 2007;110:3245-52.

(168) Heinz S, Haehnel V, Karaghiosoff M, Schwarzfischer L, Muller M, Krause SW, Rehli M. Species-specific regulation of Toll-like receptor 3 genes in men and mice. J Biol Chem. 2003;278:21502-9.

(169) Lien E, Means TK, Heine H, Yoshimura A, Kusumoto S, Fukase K, Fenton MJ, Oikawa M, Qureshi N, Monks B, Finberg RW, Ingalls RR, Golenbock DT. Toll-like receptor 4 imparts ligand-specific recognition of bacterial lipopolysaccharide. J Clin Invest. 2000;105:497-504.

(170) Nahori MA, Fournie-Amazouz E, Que-Gewirth NS, Balloy V, Chignard M, Raetz CR, Saint G, I, Werts C. Differential TLR recognition of leptospiral lipid $A$ and lipopolysaccharide in murine and human cells. J Immunol. 2005;175:6022-31.

(171) Andersen-Nissen E, Smith KD, Bonneau R, Strong RK, Aderem A. A conserved surface on Toll-like receptor 5 recognizes bacterial flagellin. J Exp Med. 2007;204:393-403.

(172) Heil F, Hemmi H, Hochrein H, Ampenberger F, Kirschning C, Akira S, Lipford G, Wagner H, Bauer S. Species-specific recognition of single-stranded RNA via toll-like receptor 7 and 8. Science. 2004;303:1526-9.

(173) Govindaraj RG, Manavalan B, Basith S, Choi S. Comparative analysis of species-specific ligand recognition in Toll-like receptor 8 signaling: a hypothesis. PLoS One. 2011;6:e25118.

(174) Hasan U, Chaffois C, Gaillard C, Saulnier V, Merck E, Tancredi S, Guiet C, Briere F, Vlach J, Lebecque S, Trinchieri G, Bates EE. Human TLR10 is a functional receptor, expressed by B cells and plasmacytoid dendritic cells, which activates gene transcription through MyD88. J Immunol. 2005;174:2942-50.

(175) Koblansky AA, Jankovic D, Oh H, Hieny S, Sungnak W, Mathur R, Hayden MS, Akira S, Sher A, Ghosh S. Recognition of profilin by Toll-like receptor 12 is critical for host resistance to Toxoplasma gondii. Immunity. 2013;38:119-30.

(176) Shi Z, Cai Z, Wen S, Chen C, Gendron C, Sanchez A, Patterson K, Fu S, Yang J, Wildman D, Finnell RH, Zhang D. Transcriptional regulation of the novel Toll-like receptor TIr13. J Biol Chem. 2009;284:20540-7. 